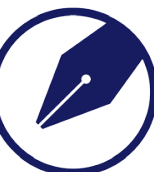

\title{
Acetonitrile Synthesis via Ammoxidation: Mo/zeolites Catalysts Screening
}

\author{
Faouzi Ayari $^{* 1}$, Emna Mannei ${ }^{1,2}$, Esther Asedegbega-Nieto ${ }^{3}$, Mourad Mhamdi ${ }^{2,4}$, Gérard Delahay $^{5}$ \\ ${ }^{1}$ Laboratory of chemical, galenic and pharmacological development of drugs, Faculty de Pharmacy of Monastir, University of Monastir, \\ Monastir, Tunisia \\ ${ }^{2}$ Material chemistry and catalysis laboratory, Faculty of Sciences of Tunis, University of Tunis El Manar, Tunis, Tunisia \\ ${ }^{3}$ Department of inorganic and technical chemistry, Faculty of Sciences, The National Distance Education University, Madrid, Spain \\ ${ }^{4}$ Higher institute of medical technologies of Tunis, University of Tunis El Manar, Tunis, Tunisia \\ ${ }^{5}$ CNRS-UM-ENSCM-MACS, Charles Gerhardt Institute in Montpellier, Montpellier, France \\ E-mail: faouzi.ayari@fst.utm.tn
}

\begin{abstract}
Mo/zeolites catalysts were investigated in ethane and ethylene ammoxidation into acetonitrile. The catalysts were prepared either in solid-solid or liquid-solid interface after varying different parameters. The stabilization of Mo species upon the exchange is dependent on the hydrophilic/hydrophobic character of the zeolite and the type of Mo precursor. In fact, zeolites with low $\mathrm{Si} / \mathrm{Al}$ molar ratios should be avoided due to their higher dehydration enthalpy values $\left(\Delta_{\text {dehyd }} \cdot \mathrm{H}\right)$. On the other hand, the use of $\mathrm{MoOCl}_{4}, \mathrm{Mo}(\mathrm{CO})_{6}$ and $\mathrm{MoCl}_{3}$ precursors and zeolites with high $\mathrm{Si} / \mathrm{Al}$ ratios led to inefficient $\left[\mathrm{Mo}_{7} \mathrm{O}_{24}\right]^{6-}$ species and amorphous $\mathrm{MoO}_{3}$ which catalyzes the combustion reaction. Nevertheless, the use of $\mathrm{MoCl}_{5}, \mathrm{MoO}_{3}$ and $\mathrm{MoO}_{2}\left(\mathrm{C}_{5} \mathrm{H}_{7} \mathrm{O}_{2}\right)_{2}$ led to promising activities. In catalysis, $\left[\mathrm{MoO}_{4}\right]^{2-}$ species are required to activate $\mathrm{C}_{2} \mathrm{H}_{6}$ into $\mathrm{C}_{2} \mathrm{H}_{4}$, while $\left[\mathrm{Mo}_{x} \mathrm{O}_{x+1}\right]^{2-}(x=1,2)$ species catalyze the ammoniation of $\mathrm{C}_{2} \mathrm{H}_{4}$ and the ethylamine dehydrogenation into $\mathrm{CH}_{3} \mathrm{CN}$. Interestingly, active catalysts could be obtained by humid impregnation and a simultaneous oxidative treatment. Such a treatment improves the dispersion state of crystalline $\mathrm{MoO}_{3}$, which activate ethane molecules. It is judicious to perform $\mathrm{C}_{2} \mathrm{H}_{6}$ oxidative dehydrogenation before ammoxidation since the interference between the different investigated parameters could be noted.

Keywords: Offretite, Ferrierite, Dehydration Enthalpy, Band Gap, $\mathrm{MoO}_{3}$
\end{abstract}

\section{Introduction}

Will the world have enough ethane?

According to the statistics, $80 \%$ of the global production of $\mathrm{C}_{2} \mathrm{H}_{6}$ comes from 10 nations. However, ethane is difficult to transport and $\sim 660$ Trillion BTU of this hydrocarbon is either rejected in the natural gas or flared, leading to a waste of valuable resources ${ }^{[1,2]}$. Fortunately, efforts were consented in the conversion of ethane to liquid hydrocarbons inside the natural gas deposits. Compared with ethane, ethylene is easier to convert into valuables liquids such as nitriles and therefore, the activation of $\mathrm{C}_{2} \mathrm{H}_{6}$ is a crucial step in the ethane-to-liquids technology.

Our group ${ }^{[3,4,5]}$ has reported Mo/zeolites as efficient catalysts for ethane ammoxidation (Eq. 1) into acetonitrile (AN). The reaction in Eq. (1) is the sum of Eqs. (2), (3) and (4) ${ }^{[6]}$.

$$
\begin{aligned}
& \mathrm{C}_{2} \mathrm{H}_{6}+\mathrm{NH}_{3}+1.5 \mathrm{O}_{2} \rightarrow \mathrm{CH}_{3} \mathrm{CN}+3 \mathrm{H}_{2} \mathrm{O} \\
& \mathrm{C}_{2} \mathrm{H}_{6}+0.5 \mathrm{O}_{2} \rightarrow \mathrm{C}_{2} \mathrm{H}_{4}+\mathrm{H}_{2} \mathrm{O} \\
& \mathrm{C}_{2} \mathrm{H}_{4}+\mathrm{NH}_{3} \leftrightarrow \mathrm{CH}_{3} \mathrm{CH}_{2} \mathrm{NH}_{2} \\
& \mathrm{CH}_{3} \mathrm{CH}_{2} \mathrm{NH}_{2}+\mathrm{O}_{2} \rightarrow \mathrm{CH}_{3} \mathrm{CN}+2 \mathrm{H}_{2} \mathrm{O}
\end{aligned}
$$

However, ethylene ammoxidation (Eq. 5) is the sum of Eqs. (3) and (4) and, therefore, $\mathrm{C}_{2} \mathrm{H}_{4}$ is an intermediate during $\mathrm{C}_{2} \mathrm{H}_{6}$ ammoxidation ${ }^{[6]}$.

Copyright (C2020 Faouzi Ayari, et al.

DOI: https://doi.org/10.37256/fce.112020117.16-30

This is an open-access article distributed under a CC BY license

(Creative Commons Attribution 4.0 International License)

https://creativecommons.org/licenses/by/4.0/ 


$$
\mathrm{C}_{2} \mathrm{H}_{4}+\mathrm{NH}_{3}+\mathrm{O}_{2} \rightarrow \mathrm{CH}_{3} \mathrm{CN}+2 \mathrm{H}_{2} \mathrm{O}
$$

The manufacture of acetonitrile via ammoxidation has attracted the attention of scientists till date ${ }^{[5,7]}$. In fact, AN is particularly used as electrolyte in dye-sensitized solar cells ${ }^{[8]}$ (dipole moment $\sim 3.44$ Debye $^{[9]}$ ). Given the fact that AN is produced as a by-product during acrylonitrile manufacture, the growing demand for acrylonitrile products has led to a severe AN shortage mainly in the pharmaceutical industry ${ }^{[10]}$. However, the unexpected AN shortages can offer the opportunity for scientists to develop novel $\mathrm{C}_{2} \mathrm{H}_{6}$ ammoxidation catalysts ${ }^{[11,12]}$.

The aim of this work is to study $\mathrm{C}_{2} \mathrm{H}_{6}$ and $\mathrm{C}_{2} \mathrm{H}_{4}$ ammoxidation into acetonitrile over Mo/zeolites catalysts. We performed a general screening of numerous catalysts issued from different zeolites' structure, Mo precursors, Si/Al molar ratio and Mo wt. $\%$ in order to optimize the adequate preparation parameters. Simultaneously, different characterization techniques have been used to study the physicochemical properties of the prepared solids.

\section{Materials and Methods}

\subsection{Catalysts preparation}

The samples were prepared by solid-state ion exchange (SSIE), which consists on grinding the zeolite and the Mo salt before being heated under a carrier gas from 30 to $500^{\circ} \mathrm{C}\left(2^{\circ} \mathrm{C} \mathrm{min}^{-1}\right)$ and then kept isothermally for $12 \mathrm{~h}$ at $500^{\circ} \mathrm{C}$. Several reference solids were prepared either by SSIE or impregnation (Imp). The later method consists on mixing the zeolite with an aqueous solution containing the desired quantity of Mo precursor. For this purpose, the precursor was dispersed in a small quantity of water using sonication and, after the impregnation of the zeolite support, the resulting slurry was dried in oven at $100^{\circ} \mathrm{C}$ overnight before being treated under carrier gas for $12 \mathrm{~h}$ at $500^{\circ} \mathrm{C}$. More details are available in Tables 1 and S1.

Table 1. List of the prepared solids

\begin{tabular}{|c|c|c|c|c|c|c|}
\hline No & Sample & Zeolite & $\mathbf{S i} / \mathbf{A l}$ & Precursor & Treatment gas & Mo wt. \% \\
\hline \multicolumn{7}{|c|}{ Solid-state ion exchange } \\
\hline I & Mo-OFF & $\mathrm{H}-\mathrm{OFF}$ & 4 & $\mathrm{MoCl}_{3}$ & $\mathrm{He}$ & 9 \\
\hline II & Mo-FER & $\mathrm{NH}_{4}^{+}-\mathrm{FER}$ & 10 & $\mathrm{MoCl}_{3}$ & $\mathrm{He}$ & 9 \\
\hline III & $\mathrm{Z} 26\left(\mathrm{MoCl}_{3}\right)$ & $\mathrm{NH}_{4}^{+}-\mathrm{ZSM}-5$ & 26 & $\mathrm{MoCl}_{3}$ & $\mathrm{He}$ & 6 \\
\hline IV & $\mathrm{Z} 15\left(\mathrm{MoCl}_{3}\right)$ & $\mathrm{H}^{+}-\mathrm{ZSM}-5$ & 15 & $\mathrm{MoCl}_{3}$ & $\mathrm{He}$ & 9 \\
\hline $\mathrm{V}$ & $\operatorname{MOR}\left(\mathrm{MoCl}_{3}\right)$ & $\mathrm{NH}_{4}^{+}-\mathrm{MOR}$ & 10 & $\mathrm{MoCl}_{3}$ & $\mathrm{He}$ & 9 \\
\hline VI & $\mathrm{BEA}\left(\mathrm{MoCl}_{3}\right)$ & $\mathrm{NH}_{4}^{+}-\mathrm{BEA}$ & 12.5 & $\mathrm{MoCl}_{3}$ & $\mathrm{He}$ & 9 \\
\hline VII & $\mathrm{Z} 26\left(\mathrm{MoOCl}_{4}\right)$ & $\mathrm{NH}_{4}^{+}-\mathrm{ZSM}-5$ & 26 & $\mathrm{MoOCl}_{4}$ & $\mathrm{He}$ & 6 \\
\hline VIII & $\mathrm{Z} 26\left(\mathrm{MoCl}_{5}\right)$ & $\mathrm{NH}_{4}^{+}-\mathrm{ZSM}-5$ & 26 & $\mathrm{MoCl}_{5}$ & $\mathrm{He}$ & 6 \\
\hline IX & $\mathrm{Z} 26(\mathrm{MoCO})^{*}$ & $\mathrm{NH}_{4}^{+}-\mathrm{ZSM}-5$ & 26 & $\mathrm{Mo}(\mathrm{CO})_{6}$ & $\mathrm{He}$ & 6 \\
\hline$X$ & Z26(MoAcac) & $\mathrm{NH}_{4}^{+}-\mathrm{ZSM}-5$ & 26 & $\mathrm{MoO}_{2}\left(\mathrm{C}_{5} \mathrm{H}_{7} \mathrm{O}_{2}\right)_{2}$ & $\mathrm{He}$ & 6 \\
\hline XI & $\mathrm{Z} 26\left(\mathrm{MoO}_{3}\right) 6 \% \mathrm{He}$ & $\mathrm{NH}_{4}^{+}-\mathrm{ZSM}-5$ & 26 & $\mathrm{MoO}_{3}$ & $\mathrm{He}$ & 6 \\
\hline XII & $\mathrm{BEA}\left(\mathrm{MoO}_{3}\right)$ & $\mathrm{NH}_{4}^{+}-\mathrm{BEA}$ & 12.5 & $\mathrm{MoO}_{3}$ & $\mathrm{He}$ & 6 \\
\hline XIIII & BEA(MoAcac) & $\mathrm{NH}_{4}^{+}-\mathrm{BEA}$ & 12.5 & $\mathrm{MoO}_{2}\left(\mathrm{C}_{5} \mathrm{H}_{7} \mathrm{O}_{2}\right)_{2}$ & $\mathrm{He}$ & 6 \\
\hline XIV & BEA(MoCO) & $\mathrm{NH}_{4}^{+}-\mathrm{BEA}$ & 12.5 & $\mathrm{Mo}(\mathrm{CO})_{6}$ & $\mathrm{He}$ & 6 \\
\hline XV & $\mathrm{BEA}\left(\mathrm{MoCl}_{5}\right)$ & $\mathrm{NH}_{4}^{+}-\mathrm{BEA}$ & 12.5 & $\mathrm{MoCl}_{5}$ & $\mathrm{He}$ & 6 \\
\hline XVI & $\operatorname{BEA}\left(\mathrm{MoOCl}_{4}\right)$ & $\mathrm{NH}_{4}^{+}-\mathrm{BEA}$ & 12.5 & $\mathrm{MoOCl}_{4}$ & $\mathrm{He}$ & 6 \\
\hline XVII & $\mathrm{BEA}\left(\mathrm{Mo}_{7} \mathrm{O}_{24}\right)$ & $\mathrm{NH}_{4}^{+}-\mathrm{BEA}$ & 12.5 & $\left(\mathrm{NH}_{4}\right)_{6} \mathrm{Mo}_{7} \mathrm{O}_{24}$ & $\mathrm{He}$ & 6 \\
\hline \multicolumn{7}{|c|}{ Reference materials } \\
\hline XVIII & $\mathrm{Z} 26\left(\mathrm{MoO}_{3}\right) 10 \% \mathrm{He}$ & $\mathrm{NH}_{4}^{+}-\mathrm{ZSM}-5$ & 26 & $\mathrm{MoO}_{3}$ & $\mathrm{He}$ & 10 \\
\hline XIX & $\mathrm{Z} 140\left(\mathrm{MoO}_{3}\right) 6 \% \mathrm{He}$ & $\mathrm{NH}_{4}^{+}-\mathrm{ZSM}-5$ & 140 & $\mathrm{MoO}_{3}$ & $\mathrm{He}$ & 6 \\
\hline $\mathrm{XX}$ & $\mathrm{Z} 15\left(\mathrm{MoO}_{3}\right) \operatorname{Imp} 2 \%$ & $\mathrm{H}^{+}-\mathrm{ZSM}-5$ & 15 & $\mathrm{MoO}_{3}$ & $\mathrm{O}_{2}$ & 2 \\
\hline XXI & $\mathrm{Z} 15\left(\mathrm{MoO}_{3}\right) \mathrm{Imp} 4 \%$ & $\mathrm{H}^{+}-\mathrm{ZSM}-5$ & 15 & $\mathrm{MoO}_{3}$ & $\mathrm{O}_{2}$ & 4 \\
\hline XXII & $\mathrm{Z} 40\left(\mathrm{MoO}_{3}\right) \operatorname{Imp} 2 \%$ & $\mathrm{H}^{+}-\mathrm{ZSM}-5$ & 40 & $\mathrm{MoO}_{3}$ & $\mathrm{O}_{2}$ & 2 \\
\hline XXIII & $\mathrm{Z} 40\left(\mathrm{MoO}_{3}\right) \mathrm{Imp} 4 \%$ & $\mathrm{H}^{+}-\mathrm{ZSM}-5$ & 40 & $\mathrm{MoO}_{3}$ & $\mathrm{O}_{2}$ & 4 \\
\hline XXIV & $\mathrm{Z} 26\left(\mathrm{MoO}_{3}\right) 6 \% \mathrm{O}_{2}$ & $\mathrm{NH}_{4}^{+}-\mathrm{ZSM}-5$ & 26 & $\mathrm{MoO}_{3}$ & $\mathrm{O}_{2}$ & 6 \\
\hline XXV & $\mathrm{Z} 140\left(\mathrm{MoO}_{3}\right) 6 \% \mathrm{He}$ & $\mathrm{NH}_{4}^{+}-\mathrm{ZSM}-5$ & 140 & $\mathrm{MoO}_{3}$ & $\mathrm{O}_{2}$ & 6 \\
\hline
\end{tabular}

*See ref. [5]

\subsection{Catalytic tests and characterization techniques}

Details about catalytic tests are available in the supplementary information section (p. S1). The chemical analyses have been performed by inductively coupled plasma (ICP) and energy dispersive X-ray (EDX). 
Textural, structural and morphological studies have been performed by $\mathrm{N}_{2}$ physisorption, X-ray diffraction (XRD), scanning electron microscopy (SEM) and transmission electron microscopy (TEM). The metal oxidation states were studied by X-ray photoelectron and UV/Vis diffuse reflectance spectroscopies (XPS and DRS). The redox features were investigated by temperature programmed reduction under hydrogen atmosphere $\left(\mathrm{H}_{2}-\mathrm{TPR}\right)$, while the acidity was studied by ammonia thermo-desorption $\left(\mathrm{NH}_{3}\right.$-TPD) and diffuse reflectance infrared Fourier transform spectroscopy (DRIFTS).

\section{Results}

\subsection{Catalytic behaviour of Mo containing catalysts \\ 3.1.1 OFF, FER and MFI issued solids}

The catalytic behaviour of the prepared solids is compiled in Tables S2-S4. Mo-OFF and Mo-FER catalysts exhibited low activities due to their particular structures and the nature of stabilized Mo species.

The catalysts No III-VI exhibited diverse catalytic activities. At 7\% of ethane conversion, Z26 $\left(\mathrm{MoCl}_{3}\right)$ led to the highest AN selectivity at $500^{\circ} \mathrm{C}\left(49 \%\right.$, vs. $4 \%$ for the inactive $\mathrm{MOR}\left(\mathrm{MoCl}_{3}\right)$ solid). In particular, $\mathrm{BEA}\left(\mathrm{MoCl}_{3}\right)$ led to the highest activity and selectivity toward ethylene(respectively $0.40 \mu \mathrm{mols}^{-1} \mathrm{~g}^{-1}$ and $17 \%$ vs. $0.20 \mu \mathrm{mols}^{-1} \mathrm{~g}^{-1}$ and $10 \%$ for $\mathrm{Z} 15\left(\mathrm{MoCl}_{3}\right)$ at $\left.500^{\circ} \mathrm{C}\right)$.

At $6 \%$ of ethylene conversion, $\mathrm{MOR}\left(\mathrm{MoCl}_{3}\right)$ exhibited the lowest AN selectivity, while $\mathrm{Z} 26\left(\mathrm{MoCl}_{3}\right)$ exhibited the highest activity at $500^{\circ} \mathrm{C}\left(13.70 \mu \mathrm{mols} s^{-1} \mathrm{~g}^{-1}\right.$ vs. 11.40 and $6.70 \mu \mathrm{mols}^{-1} \mathrm{~g}^{-1}$ for $\mathrm{Z} 15\left(\mathrm{MoCl}_{3}\right)$ and $\mathrm{BEA}\left(\mathrm{MoCl}_{3}\right)$, respectively).

Given the fact that ZSM-5 zeolite $(\mathrm{Si} / \mathrm{Al}=26)$ led to the best catalytic results, we used this support to introduce Mo at different oxidation states $\left(\mathrm{Mo}^{V I}, \mathrm{Mo}^{V}\right.$ and metallic Mo) as they play a crucial role in oxidation and hydrogenation reactions ${ }^{[13]}$.

The catalytic activities obtained in ethane ammoxidation (Table S2) revealed that $\mathrm{Z} 26\left(\mathrm{Mo}^{\mathrm{VI}} \mathrm{OCl}_{4}\right)$ and $\mathrm{Z} 26\left(\mathrm{Mo}^{\mathrm{VI}} \mathrm{Acac}\right)$ are poorly active solids (AN activity: 0.30 and $0.40 \mu \mathrm{mols}^{-1} \mathrm{~g}^{-1}$, respectively, at $500^{\circ} \mathrm{C}$ ) if compared with $\mathrm{Z} 26\left(\mathrm{Mo}^{\vee} \mathrm{Cl}_{5}\right)$. On the other hand, the use of Mo in its lowest and highest oxidation states (i.e. by using, respectively, $\mathrm{Mo}(\mathrm{CO})_{6}$ and $\mathrm{MoO}_{3}$ precursors) led to promising catalytic properties ( 0.90 and $1.20 \mu \mathrm{mols}^{-1} \mathrm{~g}^{-1}$ of AN activity, respectively, at $\left.500^{\circ} \mathrm{C}\right)$.

In ethylene ammoxidation, the situation is different. As refers to the solids obtained from $\mathrm{Cl}$-containing precursors, $\mathrm{Z} 26\left(\mathrm{MoCl}_{5}\right)$ exhibited the highest activity, while the activity of $\mathrm{Z} 26\left(\mathrm{MoCl}_{3}\right)$ and $\mathrm{Z} 26\left(\mathrm{MoOCl}_{4}\right)$ catalysts is quasi-similar at $500^{\circ} \mathrm{C}$ (Table S3). However, the use of $\mathrm{MoO}_{3}$ at different Mo contents led to noticeable divergence in the activities over $\mathrm{Z} 26\left(\mathrm{MoO}_{3}\right) 6 \% \mathrm{He}$ and $\mathrm{Z} 26\left(\mathrm{MoO}_{3}\right) 10 \% \mathrm{He}\left(8.90\right.$ and $26.50 \mu \mathrm{mols}^{-1} \mathrm{~g}^{-1}$, respectively, Tables S3 and S4).

Concerning the effect of Mo oxidation state, the data compiled in Table $\mathrm{S} 3$ indicate that the catalyst obtained from $\mathrm{Mo}^{V I} \mathrm{O}_{2}\left(\mathrm{C}_{5} \mathrm{H}_{7} \mathrm{O}_{2}\right)_{2}$ is poorly active if compared with $\mathrm{Z} 26(\mathrm{MoCO})$ (respectively 5.40 and $20.90 \mu \mathrm{mols}^{-1} \mathrm{~g}^{-1}$ of AN activity at $500^{\circ} \mathrm{C}$ ). Nevertheless, by varying $\mathrm{Si} / \mathrm{Al}$ ratio (while maintaining Mo wt. \% constant), we noticed that increasing the ratio value decreases the AN activity ( 8.90 to $5.60 \mu \mathrm{mols}^{-1} \mathrm{~g}^{-1}$, respectively, for $\mathrm{Z} 26\left(\mathrm{MoO}_{3}\right) 6 \% \mathrm{He}$ and $\mathrm{Z140}\left(\mathrm{MoO}_{3}\right) 6 \% \mathrm{He}$, Tables S3 and S4).

Apparently, the $\mathrm{Si} / \mathrm{Al}$ ratio is another parameter to be considered during the preparation of ammoxidation catalysts. In line with this, the effect of both acidity (i.e. Si/Al ratio) and Mo wt. \% was studied in ethylene ammoxidation over $\mathrm{Z} 15\left(\mathrm{MoO}_{3}\right) \mathrm{Imp} 2 \%, \mathrm{Z} 15\left(\mathrm{MoO}_{3}\right) \mathrm{Imp} 4 \%, \mathrm{Z} 40\left(\mathrm{MoO}_{3}\right) \operatorname{Imp} 2 \%$ and $\mathrm{Z} 40\left(\mathrm{MoO}_{3}\right) \operatorname{Imp} 4 \%$. The obtained results indicate that $\mathrm{Z} 15\left(\mathrm{MoO}_{3}\right) \mathrm{Imp} 4 \%$ led to $100 \%$ of selectivity toward AN at $20 \%$ of ethylene conversion (Table S4). However, with the same Mo amount (4 wt. \%), the increase in $\mathrm{Si} / \mathrm{Al}$ ratio does not affect the selectivity, while the activity was declined.

\subsubsection{BEA issued solids}

Among the catalysts issued from BEA zeolite (No XII-XVII), BEA( $\left.\mathrm{MoOCl}_{4}\right)$ was found to be less-active than $\mathrm{BEA}(\mathrm{MoAcac})$ in $\mathrm{C}_{2} \mathrm{H}_{6}$ ammoxidation at $500^{\circ} \mathrm{C}$. On the other hand, both pairs of catalysts, i.e. $\mathrm{BEA}\left(\mathrm{MoO}_{3}\right) / \mathrm{BEA}(\mathrm{MoCO})$ and $\mathrm{BEA}\left(\mathrm{MoCl}_{5}\right) / \mathrm{BEA}\left(\mathrm{Mo}_{7} \mathrm{O}_{24}\right)$ exhibited similar AN activity values (Table $\mathrm{S} 2$ ).

In ethylene ammoxidation, the difference in the catalytic properties at $500^{\circ} \mathrm{C}$ is obvious (Table S3). In effect, $\mathrm{BEA}\left(\mathrm{MoO}_{3}\right)$ and BEA(MoAcac) exhibited the highest AN activities (19.30 and $18.10 \mu \mathrm{mols}^{-1} \mathrm{~g}^{-1}$, respectively), while $\mathrm{BEA}\left(\mathrm{MoCl}_{5}\right)$ and BEA( $\left.\mathrm{MoOCl}_{4}\right)$ are less-active $\left(9.20\right.$ and $9.50 \mu \mathrm{mols}^{-1} \mathrm{~g}^{-1}$, respectively). Nonetheless, $\mathrm{BEA}(\mathrm{MoCO})$ and $\mathrm{BEA}\left(\mathrm{Mo}_{7} \mathrm{O}_{24}\right)$ exhibited intermediate AN activity values (15.20 and $12.70 \mu \mathrm{mols}^{-1} \mathrm{~g}^{-1}$, respectively).

\subsection{Characterization of Mo containing solids}

\subsubsection{OFF and FER issued solids}

Table S5 summarises the chemical composition of the solids No I and II as well as their exploitable textural properties. The recorded SBET values are too low to be accurately interpreted, in particular for $\mathrm{H}^{+}$-OFF, $\mathrm{NH}_{4}^{+}$-FER and Mo-FER samples. In a similar way, and due to the presence of $\mathrm{Na}^{+}$and $\mathrm{K}^{+}$, low textural data were obtained with zeolite $\mathrm{A}^{[14]}$ and 
offretite ${ }^{[15]}$. Nevertheless, in the case of Mo-OFF solid, the $\mathrm{S}_{\mathrm{BET}}$ value was improved $\left(108 \mathrm{~m}^{2} \mathrm{~g}^{-1}\right)$ owing to the loss of cations upon SSIE.

The data compiled in Table S5 revealed that the $(\mathrm{Mo} / \mathrm{Al})_{\mathrm{XPS}}$ ratios for the solids No I and II exceed those determined by ICP, which indicates that Mo occupied the surface. Interestingly, the $(\mathrm{Mo} / \mathrm{Al})_{\mathrm{XPS}}$ ratio determined for Mo-FER solid is quite high ( 8.5 vs. 4 for Mo-OFF), evidencing that the surface contains a significant amount of metal. Effectively, the SEM analysis revealed the presence of small particles of $\mathrm{NH}_{4}{ }^{+}$-FER zeolite (Fig. S1), which indicates that the external surface is well-developed.

The XP spectrum of Mo-OFF solid (Fig. 1A) indicated the presence of $\mathrm{MoO}_{3}$ and $\mathrm{MoO}_{2}{ }^{[16]}$. The presence of such moieties was confirmed by TPR (Fig. S2), which revealed two reduction peaks at 608 and $816^{\circ} \mathrm{C}$ ascribed, respectively, to the processes described in (Eq. 6) and (Eq. 7) ${ }^{[17,18]}$.

$$
\begin{aligned}
& \mathrm{MoO}_{3}+\mathrm{H}_{2} \rightarrow \mathrm{MoO}_{2}+\mathrm{H}_{2} \mathrm{O} \\
& \mathrm{MoO}_{2}+2 \mathrm{H}_{2} \rightarrow \mathrm{Mo}+2 \mathrm{H}_{2} \mathrm{O}
\end{aligned}
$$

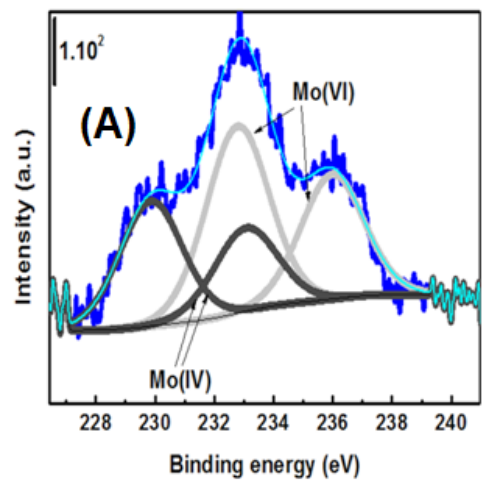

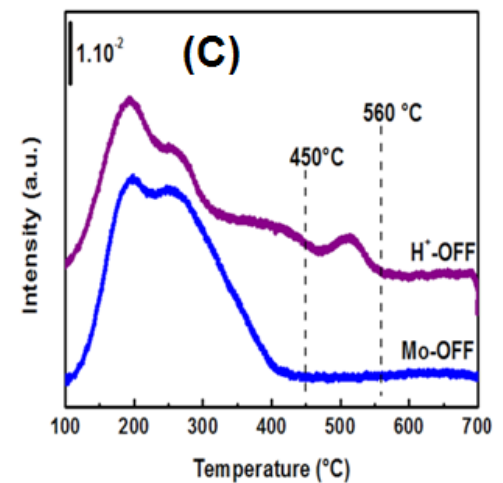

Figure 1. (A) XP spectrum of Mo-OFF solid (B) XRD patterns of Mo-OFF solid and the corresponding support, and (C) NH3-TPD profiles of Mo-OFF and H+-OFF solids

The TEM images of Mo-OFF (Fig. S3) showed tubular-like silicate crystals and small oxide particles. At the same time, the XRD pattern of this sample (Fig. 1B) showed a diffraction line ascribed to crystalline $\mathrm{MoO}_{3}$. On the other hand, the EDX analysis revealed, besides ${ }_{19} \mathrm{~K}$ (5-7 wt. \%), the homogenous dispersion of Mo at the surface ( 7 wt. \%, Table S6).

The acidity was studied by $\mathrm{NH}_{3}-\mathrm{TPD}$. The profiles of Mo-OFF and $\mathrm{H}^{+}$-OFF solids (Fig. 1C) highlighted a noticeable difference. In fact, between 450 and $560^{\circ} \mathrm{C}$, the zeolite desorbed $\mathrm{NH}_{3}$ from strong acidic sites situated inside the internal cages. However, after SSIE, this peak disappeared as the internal cages of offretite become inaccessible to $\mathrm{NH}_{3}$.

The nature of Mo species stabilized over Mo-OFF solid was estimated by the band gap energy values determined by DRS. The spectrum representing $[\mathrm{F}(\mathrm{R} \infty) \times \mathrm{hv}]^{0.5} \mathrm{vs} . \mathrm{h} v^{[4,5]}$ is illustrated in Fig. 2.

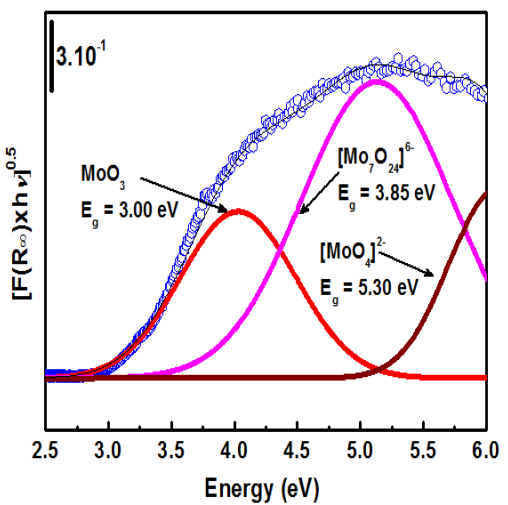

Figure 2. Optical absorption spectrum of Mo-OFF solid. F(R $\infty)$ is the Schuster-Kubelka-Munk function, while hv is the photon energy ${ }^{[4,5]}$. Eg: Edge energy

The deconvolution of Mo-OFF spectrum revealed three $\mathrm{O}^{2-} \rightarrow \mathrm{Mo}^{6+}$ charge transfer bands assigned to $\mathrm{MoO}_{3}\left(\mathrm{E}_{\mathrm{g}}=3.00\right.$ 
$\mathrm{eV}),\left[\mathrm{Mo}_{7} \mathrm{O}_{4}\right]^{6-}\left(\mathrm{E}_{\mathrm{g}}=3.85 \mathrm{eV}\right)$ and $\left[\mathrm{MoO}_{4}\right]^{2-}(\mathrm{Eg}=5.30 \mathrm{eV})^{[4,5]}$. In this spectrum, we were not able to detect the presence of $\left[\mathrm{Mo}_{2} \mathrm{O}_{7}\right]^{2-}$ species characterized by a band between 3.85 and $5.3 \mathrm{eV}$.

On comparing with the starting material, $\mathrm{NH}_{4}{ }^{+}$-FER zeolite, the SSIE of this zeolite with $\mathrm{MoCl}_{3}$ decreased the intensity of the silanol DRIFTS's band (at $3735 \mathrm{~cm}^{-1}$, Fig. 3A). On the other hand, the XPS results (Table S5) indicate that a significant fraction of Mo is present at the surface in the form of crystalline $\mathrm{MoO}_{3}$ (Figs. 3B and 3C).
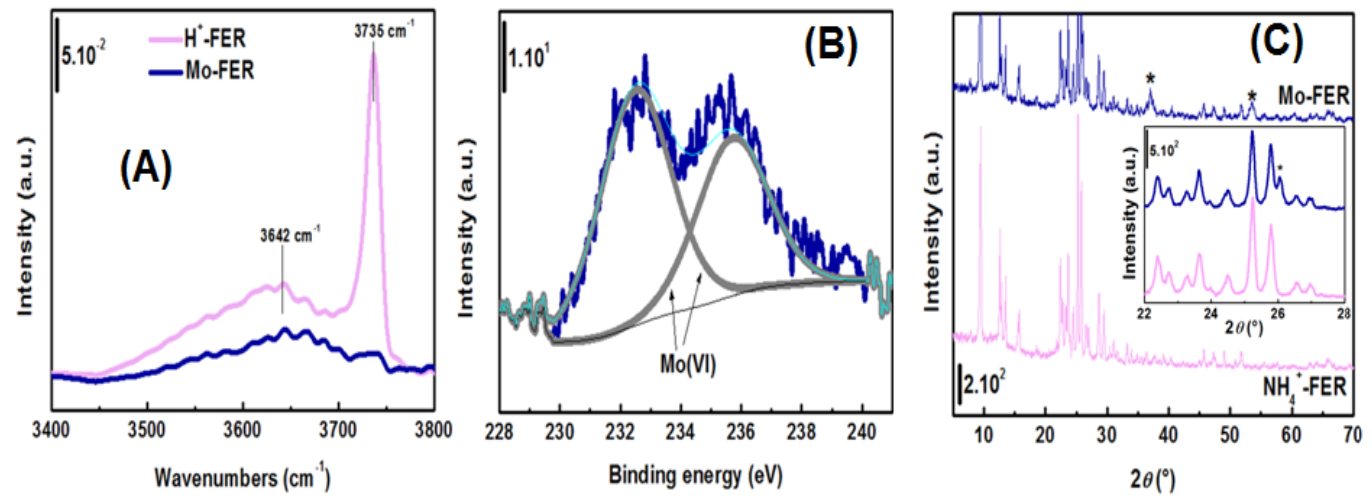

Figure 3. (A) DRIFTS spectra of H+-FER and Mo-FER solids, (B) XP spectrum of Mo-FER solid, and (C) XRD patterns of Mo-FER solid and the corresponding support

It is important to note that the intensity of the band ascribed to silanol groups in Fig. 3A is very high, which corroborates the fact that the external area of $\mathrm{NH}_{4}{ }^{+}$-FER is well-developed (Fig. S1).

\subsubsection{MFI, MOR and BEA zeolites exchanged with $\mathrm{MoCl}_{3}$}

The solids No III-VI were characterized in our previous work ${ }^{[19]}$. However, using DRS, we revealed in this study that these solids stabilized $\mathrm{MoO}_{3}$ and $\left[\mathrm{MoO}_{4}\right]^{2-}$ species (Figs. S4A-D). In particular, MOR support extended the formation of $\mathrm{MoO}_{3}$ due to its particular structure ${ }^{[19]}$, while MFI and BEA issued solids loaded with small aggregates of $\mathrm{MoO}_{3}$ (see XRD results in ${ }^{[19]}$ ). Interestingly, $\left[\mathrm{Mo}_{2} \mathrm{O}_{7}\right]^{2-}$ species were detected only over MFI solids (Figs. S4A,B and DRS results in ${ }^{[19]}$ ), while the formation of heptamers was inhibited over $\mathrm{Z} 26\left(\mathrm{MoCl}_{3}\right)$ (Fig. 4SB).

Our experience with the mechanistic study of SSIE has shown that the nature of Mo species depended on the hydration state of the zeolite. For this purpose, we determined the dehydration enthalpies $\left(\Delta_{\text {dehyd }} . \mathrm{H}\right)$ of the different zeolites (Table 2) according to Eq. $(8)^{[20]}$.

$$
\Delta_{\text {dehyd. }} \mathrm{H}=\frac{\mathrm{A} 1}{\mathrm{Si}} \times e^{\left[5.491-\left(4.674 \times\left\langle\frac{\mathrm{A} 1}{\mathrm{Si}+\mathrm{A} 1}\right\rangle\right)\right]}
$$

Table 2. Dehydration enthalpy $\left(\Delta_{\text {dehyd }} \cdot H\right)$ of the zeolites used in this study

\begin{tabular}{ccc}
\hline Zeolite & $\mathbf{S i} / \mathbf{A l} \mathbf{( m o l} / \mathbf{m o l})$ & $\boldsymbol{\Delta}_{\text {dehyd }} \mathbf{H}^{*}\left(\mathbf{k J} \mathbf{~ m o l}^{-1}\right)$ \\
\hline $\mathrm{H}^{+}-\mathrm{OFF}$ & 3.34 & 24.73 \\
$\mathrm{NH}_{4}{ }^{+}-\mathrm{FER}$ & 9.11 & 16.77 \\
$\mathrm{H}^{+}-\mathrm{ZSM}-5(\mathrm{Si} / \mathrm{Al}=15)$ & 15.66 & 11.70 \\
$\mathrm{NH}_{4}{ }^{+}-\mathrm{ZSM}-5(\mathrm{Si} / \mathrm{Al}=26)$ & 27.01 & 7.60 \\
$\mathrm{NH}_{4}{ }^{+}-\mathrm{BEA}$ & 12.21 & 13.94 \\
$\mathrm{NH}_{4}{ }^{+}-\mathrm{MOR}$ & 6.85 & 19.52 \\
\hline
\end{tabular}

According to Table 2, ZSM-5 zeolite $(\mathrm{Si} / \mathrm{Al}=26)$ exhibited the lowest $\Delta_{\text {dehyd. }} \mathrm{H}$ value, while the offretite $(\mathrm{Si} / \mathrm{Al}=3.34)$ undergoes the highest one. Seemingly, one and bi-dimensional zeolites were hardly dehydrated if compared with 3D-ones (MFI and BEA).

\subsection{3 $\mathrm{NH}_{4}{ }^{+}$-ZSM-5 (26) exchanged with $\mathrm{MoOCl}_{4}, \mathrm{MoCl}_{5}, \mathrm{Mo}(\mathrm{CO})_{6}, \mathrm{MoO}_{3}$ and $\mathrm{MoO}_{2}\left(\mathrm{C}_{5} \mathrm{H}_{7} \mathrm{O}_{2}\right)_{2}$}

This category of solids was almost characterized in our earlier works ${ }^{[3-5,18]}$. However, we represent in Table 3 the data relative to the solids No VII-XI and III for comparison purpose. 
Table 3. DZSM-5 (26) issued solids: Textural and chemical analyses results

\begin{tabular}{|c|c|c|c|c|c|c|c|c|}
\hline \multirow[b]{2}{*}{ Sample } & \multirow{2}{*}{$\begin{array}{c}\mathrm{S}_{\mathrm{BET}} / \mathrm{S}_{\text {micro }} \\
\left(\mathrm{m}^{2} \mathrm{~g}^{-1}\right)\end{array}$} & \multirow{2}{*}{$\begin{array}{l}V_{p} / V_{\text {micro }} \\
\left(\mathrm{cm}^{3} \mathrm{~g}^{-1}\right)\end{array}$} & \multicolumn{2}{|c|}{$\mathbf{S i} / \mathbf{A l}$} & \multicolumn{2}{|c|}{ Mo wt. \% } & \multicolumn{2}{|c|}{ Mo wt. loss ${ }^{*}$} \\
\hline & & & $\mathrm{ICP}^{\mathrm{a}}$ & EDX $^{\mathbf{a}}$ & ICP & EDX & ICP & EDX \\
\hline $\mathrm{NH}_{4}^{+}-\mathrm{ZSM}-5$ (26) & $367 / 291$ & $0.21 / 0.13$ & 27.01 & 28.34 & - & - & - & - \\
\hline $\mathrm{Z} 26\left(\mathrm{MoOCl}_{4}\right)$ & - & - & - & 26.17 & - & 5.14 & - & 14 \\
\hline $\mathrm{Z} 26\left(\mathrm{MoCl}_{5}\right)$ & $354 / 232$ & $0.19 / 0.10$ & 24.46 & 27.62 & 4.15 & 3.06 & 31 & 49 \\
\hline Z26(MoCO) & $269 / 182$ & $0.17 / 0.08$ & 25.15 & 25.67 & 1.86 & 3.00 & 69 & 50 \\
\hline $\mathrm{Z} 26\left(\mathrm{MoO}_{3}\right) 6 \% \mathrm{He}$ & $340 / 223$ & $0.21 / 0.10$ & 25.05 & 22.44 & 3.67 & - & 39 & - \\
\hline Z26(MoAcac) & $305 / 205$ & $0.18 / 0.09$ & 24.85 & 24.47 & 3.88 & 5.69 & 35 & 10 \\
\hline $\mathrm{Z} 26\left(\mathrm{MoCl}_{3}\right)$ & $343 / 230$ & $0.19 / 0.10$ & 26.96 & 27.56 & 4.54 & 4.90 & 24 & 18 \\
\hline
\end{tabular}

" $\left[\left(\mathrm{Mo}_{\text {theoret. }}-\mathrm{Mo}_{\text {ICP or EDX }}\right) / \mathrm{Mo}_{\text {theoret. }}\right] \times 100,{ }^{a} \mathrm{~mol} / \mathrm{mol}$

According to Table 3, the solids exhibited low Mo wt. \% if compared with the theoretical value (6 wt. \%). This behaviour would be originated from the evaporation of Mo intermediates during the SSIE procedure ${ }^{[5]}$. In particular, Z26(MoCO) solid exhibited a high metal loss ascribed to the evaporation of the precursor during the exchange ${ }^{[21]}$. On the other hand, the low SBET and porosity of this solid would be originated from the presence of oxide particles at the nearsurface $^{[5]}$.

The DRS results are compiled in Table 4. The amount and the percentage of each Mo moiety were determined by Eq. (9) upon the deconvolution of the optical spectra (see Fig. S5) and using the absorption coefficients ( $k$ ) relative to $\mathrm{MoO}_{3}$, $\left[\mathrm{Mo}_{7} \mathrm{O}_{24}\right]^{6-},\left[\mathrm{Mo}_{2} \mathrm{O}_{7}\right]^{2-}$ and $\left[\mathrm{MoO}_{4}\right]^{2-}$ determined ${ }^{[4]}$.

$$
\mathrm{C}_{\mathrm{Mo}}=A_{\mathrm{Mo}} \times k_{M o}
$$

Here, $\mathrm{C}_{\mathrm{Mo}}$ is the concentration of the Mo specie ( $\mathrm{molg}^{-1}$ ), A stands for the band's area (a.u.) depicted in Table S7 and $\mathrm{k}$ for the absorption coefficient.

Table 4. Amount and molar fraction of each Mo moiety over ZSM-5 (Si/Al = 26) issued solids

\begin{tabular}{|c|c|c|c|c|c|}
\hline \multirow[t]{2}{*}{ Sample } & \multicolumn{5}{|c|}{ Amount Mo moieties $\left(\mu \mathrm{molg}^{-1}\right)$ and the corresponding molar fraction $(\%$, value between brackets) } \\
\hline & {$\left[\mathrm{MoO}_{4}\right]^{2-}$} & {$\left[\mathrm{Mo}_{2} \mathrm{O}_{7}\right]^{2-}$} & {$\left[\mathrm{Mo}_{7} \mathrm{O}_{24}\right]^{6-}$} & $\mathrm{MoO}_{3}$ & Mo amount $\left(\mathrm{molg}^{-1}\right)$ \\
\hline $\mathrm{Z} 26\left(\mathrm{MoCl}_{5}\right)$ & - & $78.9(33)$ & - & $158(67)$ & $3.20 \times 10^{-4}$ \\
\hline $\mathrm{Z} 26\left(\mathrm{MoCl}_{3}\right)$ & $344(67)$ & $53(10)$ & - & $115(23)$ & $5.11 \times 10^{-4}$ \\
\hline $\mathrm{Z} 26(\mathrm{MoCO})$ & - & $75(36)$ & 5.4 & $126.8(61)$ & $3.13 \times 10^{-4}$ \\
\hline $\mathrm{Z} 26\left(\mathrm{MoO}_{3}\right) 6 \% \mathrm{He}$ & $\mathrm{ND}^{*}$ & $28(8.5)$ & 5.11 & $10.5(3.2)$ & - \\
\hline $\mathrm{Z} 26\left(\mathrm{MoOCl}_{4}\right)$ & $340(64)$ & $80(15)$ & 6.5 & $108(20)$ & $5.36 \times 10^{-4}$ \\
\hline Z26(MoAcac) & $418(70)$ & $50(8)$ & 4.3 & $121(20)$ & $5.93 \times 10^{-4}$ \\
\hline
\end{tabular}

"The band in ref. [18] is not credulous

Whatever the oxidation state of Mo in the used precursor, the DRS results indicate that SSIE stabilizes $\mathrm{Mo}^{V I}$ species.

The data compiled in Table 4 indicate that $\mathrm{Z} 26(\mathrm{MoAcac}), \mathrm{Z} 26\left(\mathrm{MoOCl}_{4}\right)$ and $\mathrm{Z} 26\left(\mathrm{MoO}_{3}\right) 6 \% \mathrm{He}$ stabilized the four Mo moieties (Fig. S5 and ${ }^{[18]}$ ). However, the formation of $\left[\mathrm{MoO}_{4}\right]^{2-}$ was inhibited over $\mathrm{Z} 26(\mathrm{MoCO})$, while $\mathrm{Z} 26\left(\mathrm{MoCl}_{5}\right)$ stabilized only $\mathrm{MoO}_{3}$ and $\left[\mathrm{Mo}_{2} \mathrm{O}_{7}\right]^{2-}$ moieties ${ }^{[4,5]}$. On the other hand, the XRD patterns (Fig. S6) pointed out the presence of an amorphous oxide phase over $\mathrm{Z} 26(\mathrm{MoCO}), \mathrm{Z} 26(\mathrm{MoAcac}), \mathrm{Z} 26\left(\mathrm{MoCl}_{5}\right)$ and $\mathrm{Z} 26\left(\mathrm{MoO}_{3}\right) 6 \% \mathrm{He}$ as the baseline peak at low $2 \theta$ values is quite broad, while the pattern of $\mathrm{Z} 26\left(\mathrm{MoO}_{3}\right) 6 \% \mathrm{He}$ revealed the diffraction lines of crystalline $\mathrm{MoO}_{3}$.

The data in Table 4 indicates, additionally, that the concentration of $\left[\mathrm{Mo}_{7} \mathrm{O}_{24}\right]^{6-}$ species is low. On the other hand, $\mathrm{Z} 26\left(\mathrm{MoCl}_{3}\right)$ and $\mathrm{Z2} 6\left(\mathrm{MoOCl}_{4}\right)$ presented quasi-similar percentages of $\mathrm{MoO}_{3}$, $\left[\mathrm{MoO}_{4}\right]^{2-}$ and $\left[\mathrm{Mo}_{2} \mathrm{O}_{7}\right]^{2-}$ moieties. However, $\mathrm{Z} 26\left(\mathrm{MoO}_{3}\right) 6 \% \mathrm{He}$ exhibited low amount of $\mathrm{MoO}_{3}$ specie, while the percentage of dimeric Mo is identical to that determined for $\mathrm{Z} 26(\mathrm{MoAcac})$. Interestingly, $\mathrm{Z} 26\left(\mathrm{MoCl}_{5}\right)$, Z26(MoCO) and $\mathrm{Z} 26\left(\mathrm{MoOCl}_{4}\right)$ contain quasi-similar amounts of $\left[\mathrm{Mo}_{2} \mathrm{O}_{7}\right]^{2-}$ species.

\subsection{4 $\mathrm{NH}_{4}{ }^{+}$-BEA issued solids}

The textural properties and the chemical composition of the solids No XII-XVII are compiled in Table 5. 
Table 5. BEA issued solids: Textural and chemical analyses results

\begin{tabular}{ccccc}
\hline Sample & $\mathbf{S}_{\text {BET }} / \mathbf{S}_{\text {micro }}\left(\mathbf{m}^{\mathbf{2}} \mathbf{g}^{-\mathbf{1}}\right)$ & $\mathbf{V}_{\mathbf{p}} / \mathbf{V}_{\text {micro }}\left(\mathbf{c m}^{\mathbf{3}} \mathbf{g}^{\mathbf{1}}\right)$ & ${\mathbf{M o ~ w t . ~} \mathbf{\%}^{\mathbf{a}}}$ & $\mathbf{M o ~ w t . ~ l o s s}^{\mathbf{b}}$ \\
\hline $\mathrm{NH}_{4}^{+}-\mathrm{BEA}$ & $470 / 274$ & $0.82 / 0.13$ & - & - \\
$\mathrm{BEA}\left(\mathrm{MoCl}_{3}\right)$ & $414 / 267$ & $0.55 / 0.12$ & 6.14 & 33 \\
$\mathrm{BEA}\left(\mathrm{MoO}_{3}\right)$ & $540 / 331$ & $0.59 / 0.15$ & 5.90 & Low \\
$\mathrm{BEA}(\mathrm{MoAcac})$ & $460 / 278$ & $0.55 / 0.13$ & 6.07 & - \\
$\mathrm{BEA}(\mathrm{MoCO})$ & $536 / 325$ & $0.59 / 0.15$ & 5.09 & 15 \\
$\mathrm{BEA}\left(\mathrm{MoCl}_{5}\right)$ & $463 / 269$ & $0.56 / 0.12$ & 6.10 & - \\
$\mathrm{BEA}\left(\mathrm{Mo}_{7} \mathrm{O}_{24}\right)$ & $361 / 226$ & $0.21 / 0.10$ & See Table S8 & - \\
$\mathrm{BEA}\left(\mathrm{MoOCl}_{4}\right)$ & - & - & 5.15 & 14 \\
\hline
\end{tabular}

${ }^{\mathrm{a}}$ Determined by EDX, ${ }^{\mathrm{b}}\left[\left(\mathrm{Mo}_{\text {theoret. }}-\mathrm{Mo}_{\mathrm{EDX} .}\right) / \mathrm{Mo}_{\text {theoret. }}\right] \times 100$

The zeolite support possesses a high porous volume, which facilitates the accessibility of $\mathrm{Mo}(\mathrm{CO})_{6}$ toward the internal cavities and reduces, therefore, the Mo wt. loss over BEA(MoCO) solid (15\% vs. 50\% for Z26(MoCO)).

The $\mathrm{S}_{\mathrm{BET}}$ and $\mathrm{S}_{\text {micro }}$ values do not follow a particular trend. Using Rouquerol conditions (for $\mathrm{S}_{\mathrm{BET}}$ ) and Harkns-Jura equation (for external area), suitable values were obtained with $\mathrm{Co} / \mathrm{BEA}$ solids ${ }^{[12]}$. Nevertheless, remarkable values were observed in Table 5; the low $\mathrm{S}_{\mathrm{BET}}$ and $\mathrm{V}_{\mathrm{p}}$ of $\mathrm{BEA}\left(\mathrm{Mo}_{7} \mathrm{O}_{24}\right)$. This outstanding behaviour evidences that most of the Mo introduced occupied the micropores since the metal content determined by EDX is low (Table S8).

The quantification of Mo species by DRS required the determination of the absorption coefficients (K) in Eq. (9). As a matter of fact, we used the areas estimated by the deconvolution of the spectra given in Fig. (4) and the Gauss-Jordan elimination method ${ }^{[22]}$.

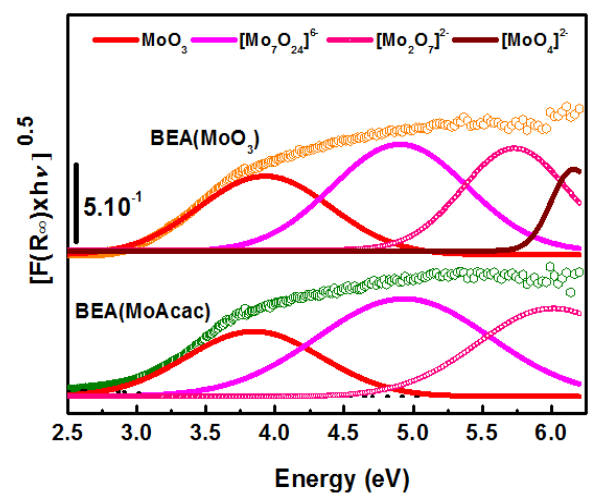

Figure 4. Optical absorption spectra of BEA issued solids. $F(R \infty)$ is the Schuster-Kubelka-Munk function, while hv is the photon energy ${ }^{[4,5]}$

The coefficients were calculated to be $\mathrm{K}_{\left[\mathrm{MoO}_{4}\right]^{2 .}}=4.97 \times 10^{-5}, \mathrm{~K}_{\left[\mathrm{Mo}_{2} \mathrm{O}_{7}\right]^{2 .}}=4.57 \times 10^{-5}, \mathrm{~K}_{\left[\mathrm{Mo}_{7} \mathrm{O}_{24}\right]^{6 .}}=1.90 \times 10^{-5}$ and $\mathrm{K}_{\mathrm{MoO}_{3}}=$ $1.55 \times 10^{-4} \mathrm{~mol} \mathrm{~g}^{-1}(\text { a.u. })^{-1}$ and the concentrations of different Mo species were collected in Table 6 (see also Table S9).

Table 6 Amount and molar fraction of each Mo moiety over BEA issued solids

\begin{tabular}{|c|c|c|c|c|c|}
\hline \multirow{2}{*}{ Sample } & \multicolumn{5}{|c|}{$\begin{array}{c}\text { Amount of Mo moieties }\left(\mu \mathrm{molg}^{-1}\right) \text { and the corresponding molar fraction }(\%, \text { value between } \\
\text { brackets) }\end{array}$} \\
\hline & {$\left[\mathrm{MoO}_{4}\right]^{2-}$} & {$\left[\mathrm{Mo}_{2} \mathbf{O}_{7}\right]^{2-}$} & {$\left[\mathrm{Mo}_{7} \mathrm{O}_{24}\right]^{6-}$} & $\mathrm{MoO}_{3}$ & Mo amount $\left(\mathrm{molg}^{-1}\right)$ \\
\hline $\mathrm{BEA}\left(\mathrm{MoOCl}_{4}\right)$ & 101 & - & $259(48)$ & $176(33)$ & $5.36 \times 10^{-4}$ \\
\hline $\mathrm{BEA}\left(\mathrm{MoO}_{3}\right)$ & 23 & $127(21)$ & $253(41)$ & $211(34)$ & $6.14 \times 10^{-4}$ \\
\hline $\operatorname{BEA}\left(\mathrm{MoCl}_{5}\right)$ & 22 & $145(23)$ & $317(50)$ & $151(24)$ & $6.35 \times 10^{-4}$ \\
\hline $\mathrm{BEA}\left(\mathrm{MoCl}_{3}\right)$ & 60 & - & $432(68)$ & $148(23)$ & $6.40 \times 10^{-4}$ \\
\hline BEA(MoAcac) & - & $159(25)$ & $294(47)$ & $179(28)$ & $6.32 \times 10^{-4}$ \\
\hline $\mathrm{BEA}(\mathrm{MoCO})$ & 4 & $134(25)$ & $216(41)$ & $176(33)$ & $5.30 \times 10^{-4}$ \\
\hline
\end{tabular}

In Table 6, one can notice that the percentage of $\left[\mathrm{MoO}_{4}\right]^{2-}$ species is low. Apparently, during SSIE, monomeric Mo units were condensed either into $\left[\mathrm{Mo}_{7} \mathrm{O}_{24}\right]^{6-}$ or into $\left[\mathrm{Mo}_{2} \mathrm{O}_{7}\right]^{2-}$. Nevertheless, if compared with heptameric Mo, the condensation of monomeric Mo into $\left[\mathrm{Mo}_{2} \mathrm{O}_{7}\right]^{2-}$ is less-privileged since $\mathrm{BEA}\left(\mathrm{MoOCl}_{4}\right)$ solid still contains $\left[\mathrm{MoO}_{4}\right]^{2-}$ (and does not contain dimeric $\mathrm{Mo}$ ). On the other hand, $\mathrm{BEA}\left(\mathrm{MoCl}_{3}\right)$ solid, which theoretically contains 9 wt. \% of Mo, stabilizes $68 \%$ of Mo in the form of $\left[\mathrm{Mo}_{7} \mathrm{O}_{24}\right]^{6-}$ and does not stabilize dimeric Mo despite the fact that it still possesses 
monomeric Mo.

For all the samples, the entire condensation of monomeric units during SSIE does not stabilize more than $25 \%$ of dimeric Mo and $50 \%$ of polymeric Mo. Seemingly, all the used precursors were decomposed during SSIE into $\mathrm{MoO}_{3}$, which partially transformed into monomeric, dimeric and heptameric species. This is confirmed by the presence of residual $\mathrm{MoO}_{3}$ in all the samples (Table 6) in amorphous state (see the dashed-square in Fig. S8A). Conversely, $\mathrm{MoO}_{3}$ exists in crystalline state over $\mathrm{BEA}\left(\mathrm{MoO}_{3}\right)$ and $\mathrm{BEA}\left(\mathrm{Mo}_{7} \mathrm{O}_{24}\right)$ as revealed within the solid rectangles in Fig. S8B.

The TPR profiles of BEA issued solids and pure $\mathrm{MoO}_{3}$ are presented in Fig.5.

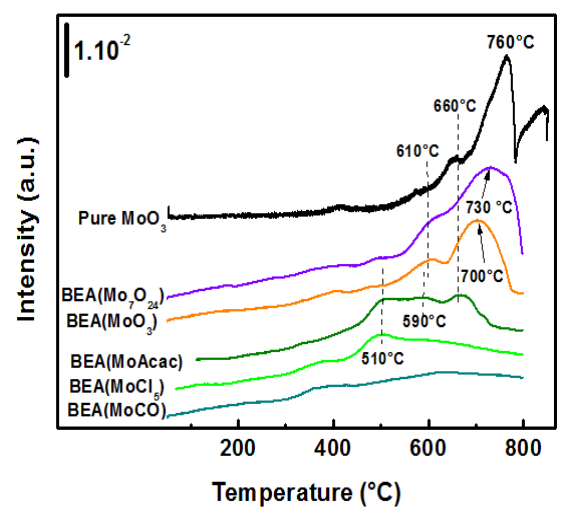

Figure 5. TPR profiles of BEA issued solids and pure $\mathrm{MoO}_{3}$

The TPR profile of $\mathrm{MoO}_{3}$ showed two main regions of $\mathrm{H}_{2}$ consumption. The first region situated below $780^{\circ} \mathrm{C}$ is related to the reduction of $\mathrm{MoO}_{3}$ (Eq. 6), while the reduction of $\mathrm{MoO}_{2}$ (Eq. 7) occurs above $780^{\circ} \mathrm{C}^{[17,18,23]}$. The TPR profiles of $\mathrm{BEA}\left(\mathrm{Mo}_{7} \mathrm{O}_{24}\right)$ and $\mathrm{BEA}\left(\mathrm{MoO}_{3}\right)$ showed two peaks at 610 and $720 \pm 10^{\circ} \mathrm{C}$ ascribed to the reduction of crystalline $\mathrm{MoO}_{3}$ (detected by XRD in Fig. S8B). In effect, the profiles of pure oxide and these two solids exhibit similar shapes. However, the profile of BEA(MoAcac) showed three broad peaks at 510,590 and $670^{\circ} \mathrm{C}$ which could be attributed to the reduction of amorphous and crystalline $\mathrm{MoO}_{3}$. It is worth to note that the profile of $\mathrm{BEA}(\mathrm{MoCO})$ does not reveal any reduction peak throughout the investigated temperature range, while for $\mathrm{BEA}\left(\mathrm{MoCl}_{5}\right)$ solid we noticed a broad $\mathrm{H}_{2}$ consumption peak at $510^{\circ} \mathrm{C}$ due to the reduction of $\mathrm{MoO}_{3}$.

\subsection{Catalytic behaviour of BEA and MFI (26) issued solids: TOF calculations}

\subsection{1 $\mathrm{NH}_{4}{ }^{+}$-ZSM-5 (26) issued solids}

Given the fact that $\left[\mathrm{Mo}_{2} \mathrm{O}_{7}\right]^{2-}$ was stabilized in all the investigated solids (Table 4), Fig. 6 (A and B) depicts the variation of the $\mathrm{TOF}_{\left.\left[\mathrm{Mo}_{2} \mathrm{O}\right]^{2}\right]^{2}}$ values as a function of temperature in ethane and ethylene ammoxidation.
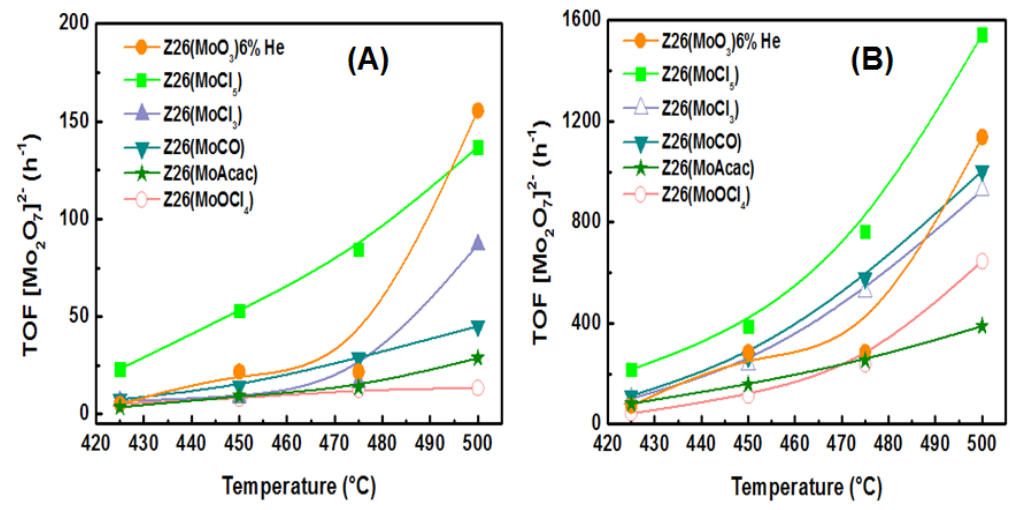

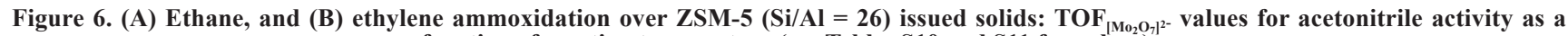
function of reaction temperature (see Tables $\mathrm{S} 10$ and $\mathrm{S} 11$ for values). 
In ethane ammoxidation, $\mathrm{Z} 26\left(\mathrm{MoCl}_{5}\right)$ catalyst exhibited the highest TOF values between $425-500^{\circ} \mathrm{C}$. Nevertheless, $\mathrm{Z} 26\left(\mathrm{MoO}_{3}\right) 6 \% \mathrm{He}$ showed the highest value at $500^{\circ} \mathrm{C}$. At $500^{\circ} \mathrm{C}, \mathrm{Z} 26\left(\mathrm{MoOCl}_{4}\right), \mathrm{Z} 26(\mathrm{MoAcac})$ and $\mathrm{Z} 26(\mathrm{MoCO})$ had turnover frequency values that did not exceed $50 h^{-1}$, while $\mathrm{Z} 26\left(\mathrm{MoCl}_{3}\right)$ offered an intermediate value $\left(\sim 75 h^{-1}\right)$.

In ethylene ammoxidation, $\mathrm{Z} 26\left(\mathrm{MoCl}_{5}\right)$ presented the highest TOF values regardless of the reaction temperature. However, the lowest values were obtained over Z26( $\left.\mathrm{MoOCl}_{4}\right)$ and Z26(MoAcac), while Z26( $\left.\mathrm{MoO}_{3}\right), \mathrm{Z26}(\mathrm{MoCO})$ and $\mathrm{Z} 26\left(\mathrm{MoCl}_{3}\right)$ showed intermediate values.

It is important to note that $\mathrm{Z} 26\left(\mathrm{MoO}_{3}\right) 6 \% \mathrm{He}$ catalyst exhibited a singular behaviour in ethane ammoxidation at $500^{\circ} \mathrm{C}$ (highest TOF value). In order to understand such behaviour, we performed XPS analyses after ethane ammoxidation (Fig.7, where we also included the spectrum of the poorly active Z26(MoAcac) catalyst).

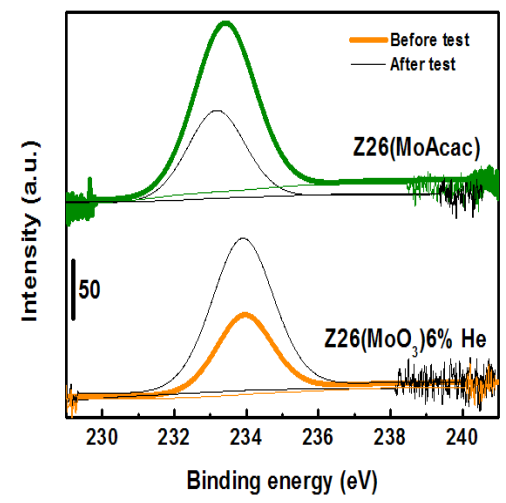

Figure 7. XP spectra of $\mathrm{Z26}\left(\mathrm{MoO}_{3}\right) 6 \% \mathrm{He}$ and $\mathrm{Z26}(\mathrm{MoAcac})$ catalysts before and after ethane ammoxidation: Mo3d5/2 component ascribed to bulky $\mathrm{MoO}_{3}$

According to Fig. 7, there is an enrichment of $\mathrm{Z} 26\left(\mathrm{MoO}_{3}\right) 6 \% \mathrm{He}$ catalyst's surface with $\mathrm{MoO}_{3}$ after catalytic test. On the contrary, the reversed trend is observed in the case of Mo(MoAcac) catalyst, i.e. $\mathrm{MoO}_{3}$ oxide migrates throughout the internal cavities of the zeolite.

\subsection{2 $\mathrm{NH}_{4}^{+}$-BEA issued solids}

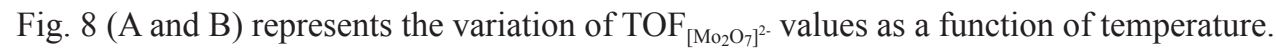
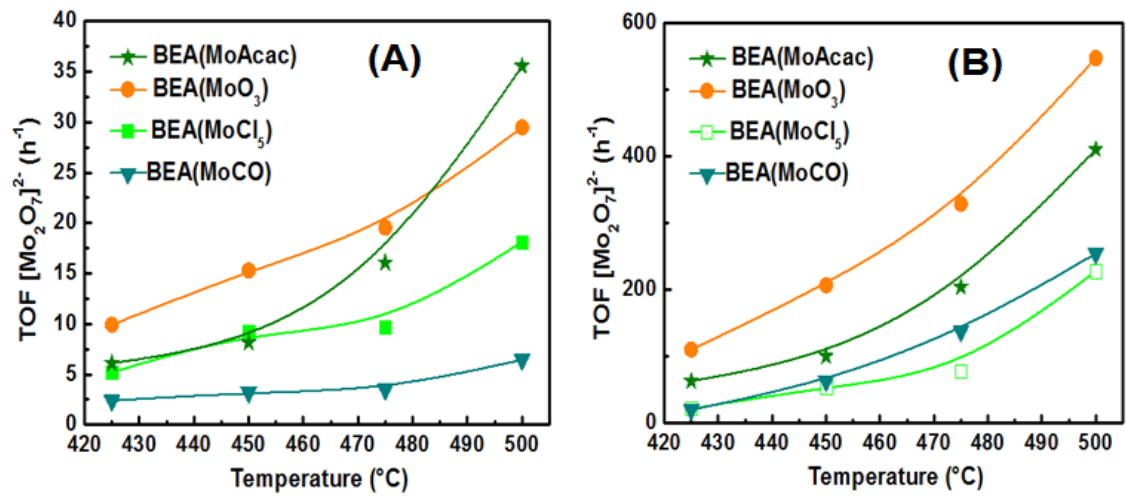

Figure 8. (A) Ethane, and (B) ethylene ammoxidation over BEA issued solids:

In the studied reactions, $\mathrm{BEA}\left(\mathrm{MoCl}_{5}\right)$ and $\mathrm{BEA}(\mathrm{MoCO})$ are poorly active catalysts. However, $\mathrm{BEA}\left(\mathrm{MoO}_{3}\right)$ exhibited the highest TOF values between 425 and $500^{\circ} \mathrm{C}$. Nevertheless, if compared with $\mathrm{BEA}\left(\mathrm{MoCl}_{5}\right), \mathrm{BEA}(\mathrm{MoAcac})$ catalyst exhibited higher turnover frequency values between 450 and $500^{\circ} \mathrm{C}$ in ethane ammoxidation.

\subsection{3 $\mathrm{MoOCl}_{4}$ issued solids}

$\mathrm{BEA}\left(\mathrm{MoOCl}_{4}\right)$ solid does not contain dimeric Mo but has $\left[\mathrm{Mo}_{7} \mathrm{O}_{24}\right]^{6-}$ species which do not catalyze the ammoxidation reaction (check the behaviour of the poorly active $\mathrm{BEA}\left(\mathrm{MoCl}_{3}\right)$ catalyst despite containing higher amounts of $\left[\mathrm{Mo}_{7} \mathrm{O}_{24}\right]^{6-}$ species). On the other hand, $\mathrm{Z} 26\left(\mathrm{MoOCl}_{4}\right)$ contains dimeric Mo and low amounts of $\left[\mathrm{Mo}_{7} \mathrm{O}_{24}\right]^{6-}$ species. Both catalysts contain monomeric Mo and exhibit similar catalytic properties (Tables S1 and S2). Bearing this in mind, the TOF values 
relative to $\left[\mathrm{MoO}_{4}\right]^{2-}$ species over $\mathrm{BEA}\left(\mathrm{MoOCl}_{4}\right)$ and $\mathrm{Z26}\left(\mathrm{MoOCl}_{4}\right)$ were calculated and compiled in Fig.S10.

According to Fig. S10 (A and B), BEA $\left(\mathrm{MoOCl}_{4}\right)$ catalyst exhibited higher TOF values if compared with $\mathrm{Z} 26\left(\mathrm{MoOCl}_{4}\right)$.

\section{Discussion}

\subsection{OFF and FER issued catalysts}

The treatment of Mo chlorides and zeolites during the SSIE would result in the formation of cationic species like $\left[\mathrm{Mo}_{2} \mathrm{Cl}_{2}\right]^{4+}$ and $[\mathrm{MoCl}]^{2+}$ instead of bare $\mathrm{Mo}^{3+[24]}$. In the OFF framework, six different oxygen atoms have been numbered ( $\mathrm{Scheme} \mathrm{Sl}^{[25]}$ ). $\mathrm{O}_{5}$ atom, located in the channels and in gmelinite cages (aperture $5 \AA$ ), is largely accessible to hydrocarbons and $\mathrm{NH}_{3}$, while $\mathrm{O}_{2}$ and $\mathrm{O}_{4}$, located in cancrinite cages (aperture $1.8 \AA$ ), are less accessible to hydrocarbons but interact with $\mathrm{NH}_{3}$. Nevertheless, $\mathrm{O}_{6}$ atom is located in hexagonal prisms, which are inaccessible to $\mathrm{NH}_{3}{ }^{[25]}$.

In the studied reactions, Mo-OFF catalyst is poorly active. Ethane (kinetic diameter $\left.\mathrm{d}=4.44 \AA^{[11]}\right)$, ethylene $(\mathrm{d}=4.00$ $\left.\AA^{[11]}\right)$, dioxygen $\left(\mathrm{d}=3.46 \AA^{[15]}\right)$ and $\mathrm{NH}_{3}\left(\mathrm{~d}=2.90 \AA^{[26]}\right)$ molecules are accessible only to the main channels and gmelinite cages of offretite. Nevertheless, $\mathrm{CH}_{3} \mathrm{CN}\left(\mathrm{d}=4.97 \AA^{[11]}\right)$ produced during ammoxidation would be trapped inside the gmelinite cages and then oxidized into $\mathrm{CO}_{2}$ (selectivity toward $\mathrm{CO}_{2} \geq 92 \%$ ). The hydrocarbon(s) molecules (reactants or intermediate), which have no access to the hexagonal prisms and cancrinite cages, will be oxidized over amorphous $\mathrm{MoO}_{3}$ $\left(\mathrm{E}_{\mathrm{g}}=3.00 \mathrm{eV}\right.$ in Fig. 3, vs. $2.88 \mathrm{eV}^{[18]}$ for commercial $\left.\mathrm{MoO}_{3}\right)$.

Ferrierite is a medium-pore sized zeolite containing a bi-dimensional pore system consisting of 10 membered ring (MR) channels $(4.3 \times 5.5 \AA)$ and $8 \mathrm{MR}$ channels $(3.5 \times 4.8 \AA)^{[27,28]}$. The interaction between molecules having permanent moment (e.g. $\mathrm{N}_{2}$ ) and the electric field of ferrierite is weak, which explains the failure of our textural analysis. At the contrary, polar $\mathrm{H} 2 \mathrm{O}$ molecules, strongly interacted with the electric field, would inhibit the entire dehydration of the ferrierite.

Under the SSIE conditions employed, the humid ferrierite sample would evolve $\mathrm{H}_{2} \mathrm{O}$ toward $\mathrm{MoCl}_{3}$ below $450^{\circ} \mathrm{C}^{[22]}$. As a matter of fact, the hygroscopic $\mathrm{MoCl}_{3}$ will be readily transformed into $\mathrm{MoOCl}_{2 \times(\mathrm{g})}(\mathrm{x}=1,1.5$ or 2) leading to a significant Mo weight loss. Furthermore, residual $\mathrm{MoOCl}_{2 \times(\mathrm{g})}$ could be transformed into $\mathrm{MoO}_{3}$ (Eq. 10) as we proposed for $\mathrm{MoCl}_{5}^{[24]}$.

$$
\mathrm{MoOCl}_{2 \times(\mathrm{g})}+2 \mathrm{H}_{2} \mathrm{O}_{(\mathrm{g})} \rightarrow \mathrm{MoO}_{3(\mathrm{~s})}+2 x \mathrm{HCl}_{(\mathrm{g})}+(2-x) \mathrm{H}_{2(\mathrm{~g})}
$$

Apparently, the reaction in Eq. (10) is displaced toward the right side since the XP spectrum of Mo-FER solid revealed the presence of, only, $\mathrm{MoO}_{3}$ at the surface. Such oxide, which hinders the surface silanol groups (see the decrease in the $3735 \mathrm{~cm}^{-1}$ band's intensity in Fig. 3A), exists in a crystalline state reduced under $\mathrm{H}_{2}$ at 550 and $630^{\circ} \mathrm{C}$.

Despite the presence of crystalline $\mathrm{MoO}_{3}$, which catalyzes the reaction in Eq. (2), Mo-FER catalyst is inactive in ethane ammoxidation. Apparently, the oxide particles sited at the catalyst's surface blocked the zeolite channels and inhibited the diffusion of $\mathrm{C}_{2} \mathrm{H}_{6}$ toward the internal active sites. As for the ethylene ammoxidation, the structure of this catalyst does not permit effective mixing of reactants as the totality of Mo occupied the surface.

\subsection{MoCl3 issued catalysts}

Upon the SSIE, the small 8 MR side-pockets $(2.6 \times 5.7 \AA)$ in mordenite ${ }^{[19]}$ favoured the formation of amorphous MoO3 agglomerates ${ }^{[19]}$, while DRS results revealed the presence of $\left[\mathrm{MoO}_{4}\right]^{2-}$ and $\left[\mathrm{Mo}_{7} \mathrm{O}_{24}\right]^{6-}$ species. In ethane ammoxidation, $\operatorname{MOR}\left(\mathrm{MoCl}_{3}\right)$ is the least active catalyst since amorphous $\mathrm{MoO}_{3}$ catalyzes the secondary reaction and inhibits the accessibility of reactants toward internal active sites. However, in ethylene ammoxidation, this catalyst exhibited an interesting behaviour due to the presence of medium-strength acid sites ${ }^{[19]}$, which easily desorbed NH3 required in Eq.(3). In fact, strong acid-sites are inefficient in acid catalysis over mordenite ${ }^{[30]}$.

The BEA issued solid exhibited superior activity if compared with $\mathrm{MOR}\left(\mathrm{MoCl}_{3}\right)$. This behaviour would be ascribed to the nature of oxide phase stabilized within BEA $\left(\mathrm{MoCl}_{3}\right)$. In effect, the XRD and TEM analyses reported in ref. ${ }^{[19]}$ indicated the presence of small aggregates of crystalline $\mathrm{MoO}_{3}$. The obstruction of the BEA channels is, therefore, excluded.

The SSIE of $\mathrm{MoCl}_{3}$ into MFI zeolites $\left(\mathrm{Si} / \mathrm{Al}=15\right.$ and 26) stabilizes, besides $\mathrm{MoO}_{3}$, monomeric and dimeric Mo. However, $\left[\mathrm{Mo}_{7} \mathrm{O}_{24}\right]^{6-}$ species were detected over $\mathrm{Z} 15\left(\mathrm{MoCl}_{3}\right)$ solid, only, due to the availability of neighbouring $\mathrm{Al}$ atoms in this $\mathrm{Al}$-rich zeolite $\left(2.44\right.$ wt. $\left.{ }^{\left[{ }^{[19]}\right.}\right)$. In catalysis, $\mathrm{Z} 15\left(\mathrm{MoCl}_{3}\right)$ and $\mathrm{Z} 26\left(\mathrm{MoCl}_{3}\right)$ exhibited remarkable activities due to the presence of $\left[\mathrm{Mo}_{2} \mathrm{O}_{7}\right]^{2-}$ species considered as potential active sites. Nevertheless, higher $\mathrm{CO}_{2}$ selectivity was recorded over $\mathrm{Z} 15\left(\mathrm{MoCl}_{3}\right)$ due to the fact that Mo species are in deep interaction with the highly-charged ZSM-5 $(\mathrm{Si} / \mathrm{Al}=15)$ framework as they were hardly reduced under $\mathrm{H}_{2}$ (see TPR results $\mathrm{in}^{[19]}$ ). During the SSIE, $\mathrm{H}_{2} \mathrm{O}$ should be evolved easily in order to 
transform $\mathrm{MoCl}_{3}$ into $\mathrm{MoOCl}_{2 \mathrm{x}}$ and then into $\mathrm{MoO}_{3}$, required to form the exchangeable $\mathrm{MoO}_{2}(\mathrm{OH})_{2}$ species (Eq. 11).

$$
\mathrm{MoO}_{3(\mathrm{~s})}+\mathrm{H}_{2} \mathrm{O}_{(\mathrm{g})}=\mathrm{MoO}_{2}(\mathrm{OH})_{2(\mathrm{~s})}=\mathrm{MoO}_{2}(\mathrm{OH})_{2(\mathrm{~g})}
$$

Nevertheless, if the zeolite is hardly dehydrated, $\mathrm{MoO}_{3}$ does not transform adequately into $\mathrm{MoO}_{2}(\mathrm{OH})_{2(\mathrm{~g})}$ during $\operatorname{SSIE}$ but rather undergoes agglomeration at the catalyst's surface and blocks the channels during ammoxidation and/or enhances the hydrocarbons oxidation.

The exchange of ZSM-5 zeolite $\left(\Delta_{\text {dehyd. }} \mathrm{H}=7.60 \mathrm{~kJ} \mathrm{~mol}^{-1}\right)$ with $\mathrm{MoCl}_{3}$ would stabilize less amounts of $\mathrm{MoO}_{3}$ than that of $\operatorname{BEA}\left(\Delta_{\text {dehyd. }} \mathrm{H}=13.94 \mathrm{~kJ}\right.$ mol-1) exchanged with the same precursor (respectively 115 and $\left.148 \mu \mathrm{molg}^{-1} \mathrm{of} \mathrm{MoO}_{3}\right)$. Therefore, during the exchange of $\mathrm{MoCl}_{3}$ into BEA, the precursor is transformed into $\mathrm{MoO}_{3}$ (Eq. 10). This oxide is then transformed into $\left[\mathrm{MoO}_{4}\right]^{2-}$ (Eq. 12) which further undergoes two possible transformations (Eqs. 13 and 14).

$$
\begin{aligned}
& \mathrm{MoO}_{3} \rightarrow \mathrm{MoO}_{2}(\mathrm{OH})_{2} \rightarrow\left[\mathrm{MoO}_{4}\right]^{2-} \\
& {\left[\mathrm{MoO}_{4}\right]^{2-} \rightarrow\left[\mathrm{Mo}_{2} \mathrm{O}_{7}\right]^{2-}} \\
& {\left[\mathrm{MoO}_{4}\right]^{2-} \rightarrow\left[\mathrm{Mo}_{7} \mathrm{O}_{24}\right]^{6-}}
\end{aligned}
$$

Over $\mathrm{Z} 26\left(\mathrm{MoCl}_{3}\right)$ solid, only reactions (10), (12) and (13) occur since no $\left[\mathrm{Mo}_{7} \mathrm{O}_{24}\right]^{6-}$ species were formed. However, in the case of BEA( $\left(\mathrm{MoCl}_{3}\right)$, only reactions (10), (12) and (14) take place. Seemingly, the condensation of monomeric Mo into $\left[\mathrm{Mo}_{7} \mathrm{O}_{24}\right]^{6-}$ over an Al-poor zeolite, i.e. $\mathrm{ZSM}-5\left(\mathrm{Si} / \mathrm{Al}=26,1.30\right.$ wt. $\%$ of $\mathrm{Al}$ vs. 2.77 for $\mathrm{BEA}^{[19]}$ ), is disfavoured.

In catalysis, $\mathrm{BEA}\left(\mathrm{MoCl}_{3}\right)$ is a poorly active solid although it contains $432 \mu \mathrm{molg}^{-1}$ of $\left[\mathrm{Mo}_{7} \mathrm{O}_{24}\right]^{6-}$ species, whereas, the superiority of $\mathrm{Z26}\left(\mathrm{MoCl}_{3}\right)$ catalyst is attributed to the presence of $53 \mu \mathrm{molg}^{-1}$ of $\left[\mathrm{Mo}_{2} \mathrm{O}_{7}\right]^{2-}$ species.

\section{3 $\mathrm{MoOCl}_{4}$ and $\mathrm{MoCl}_{5}$ issued catalysts}

$\mathrm{BEA}\left(\mathrm{MoOCl}_{4}\right)$ solid loaded, apart from monomeric Mo, higher amounts of $\mathrm{MoO}_{3}\left(176 \mu \mathrm{mol} \mathrm{g}^{-1}\right)$ and $\left[\mathrm{Mo}_{7} \mathrm{O}_{24}\right]^{6-}$ $\left(259 \mu \mathrm{mol} \mathrm{g}^{-1}\right)$, i.e. only reactions in Eqs. (10), (12) and (14) occur). However, the solid issued from ZSM-5 ( $\left.\mathrm{Si} / \mathrm{Al}=26\right)$ stabilized very high amounts of monomeric Mo $\left(340 \mu \mathrm{molg}^{-1}\right)$ and dimeric Mo $\left(80 \mu \mathrm{molg}^{-1}\right)$, i.e. reactions (12) and (13) are predominant.

In catalysis, $\left[\mathrm{MoO}_{4}\right]^{2-}$ species catalyze ethane dehydrogenation ${ }^{[31]}$ and activate ammonia molecules required for ammoxidation $^{[3]}$. Nevertheless, the variation of TOF relative to monomeric Mo revealed that $\mathrm{Z} 26\left(\mathrm{MoOCl}_{4}\right)$ is the least active catalyst despite the presence of dimeric Mo. In order to understand this controversy, we performed SEM analysis with the intention of verifying the morphology of BEA( $\left(\mathrm{MoOCl}_{4}\right)$ and $\mathrm{Z} 26\left(\mathrm{MoOCl}_{4}\right)$ solids (Fig. 9).

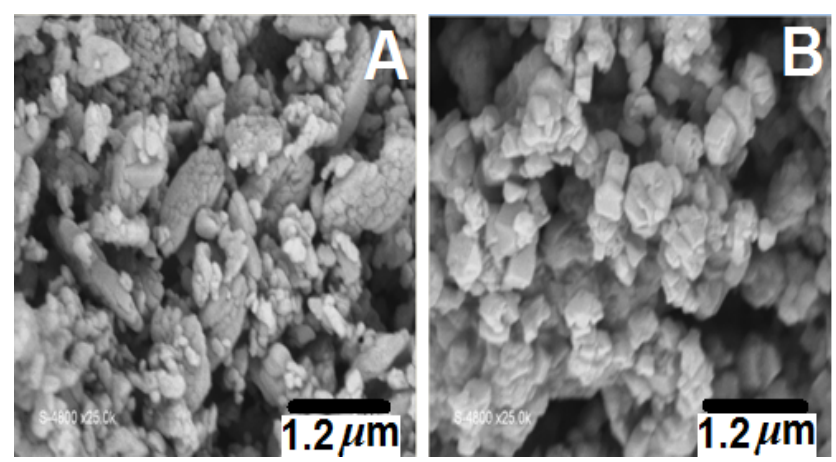

Figure 9. SEM micrograph of (A) $\mathrm{BEA}\left(\mathrm{MoOCl}_{4}\right)$, and (B) $\mathrm{Z26}\left(\mathrm{MoOCl}_{4}\right)$ solids

Fig. 9B showed that $\mathrm{Z26}\left(\mathrm{MoOCl}_{4}\right)$ contains mainly spherical agglomerates of zeolite particles, while the grains of $\mathrm{BEA}\left(\mathrm{MoOCl}_{4}\right)$ sample are less-interconnected with a size below $1.2 \mu \mathrm{m}$. Such an agglomeration over $\mathrm{Z} 26\left(\mathrm{MoOCl}_{4}\right)$ has a negative effect in ammoxidation despite the presence of dimeric Mo. In this context, Batalha et $a{ }^{[32]}$ reported that the diffusion of butane into BEA zeolite increases with the decrease in aggregates' size ${ }^{[32]}$.

The inversed trend is observed with $\mathrm{MoCl}_{5}$ issued solids. In effect, $\mathrm{Z26}\left(\mathrm{MoCl}_{5}\right)$ catalyst exhibited the highest activity, while $\mathrm{BEA}\left(\mathrm{MoCl}_{5}\right)$ is poorly active. Both solids contain dimeric Mo and a similar concentration of $\mathrm{MoO}_{3}$ reduced at the temperature $\left(510^{\circ} \mathrm{C}\right.$ in Fig. 5 and $515^{\circ} \mathrm{C}$ in $\left.{ }^{[4]}\right)$. This behaviour cannot be ascribed to the obstruction of the BEA channels by 
oxide since all the BEA issued solids exhibited a significant decrease in porosity. On the other hand, both solids contained amorphous oxide (dashed-squares in Figs. S6 and S8A).

We analyzed $\mathrm{Z} 26\left(\mathrm{MoCl}_{5}\right)$ and BEA( $\left(\mathrm{MoCl}_{5}\right)$ solids by SEM (Fig.10).
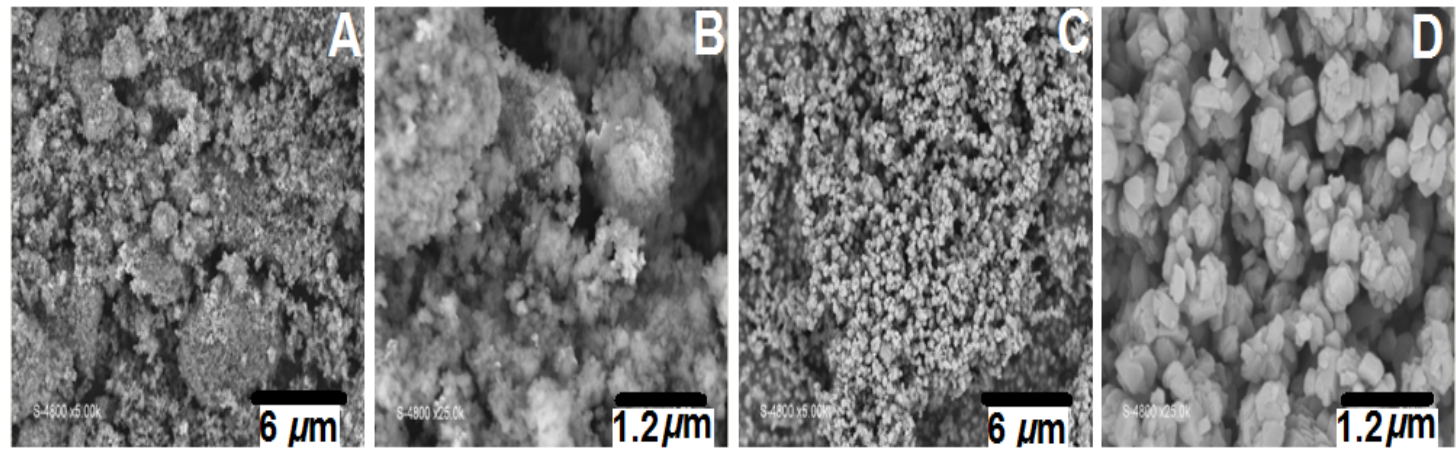

Figure 10. SEM micrographs of (A) and (B) BEA(MoCl $)$, and (C) and (D) $\mathrm{Z26}\left(\mathrm{MoCl}_{5}\right)$ solids

The micrographs revealed the aggregation of zeolite particles over BEA( $\left(\mathrm{MoCl}_{5}\right)$ solid. Similarly to $\mathrm{Z26}\left(\mathrm{MoOCl}_{4}\right)$ solid, the aggregation of the particles would inhibit the ammoxidation reactants to reach internal active sites of $\mathrm{BEA}\left(\mathrm{MoCl}_{5}\right.$ ) catalyst, namely monomeric and dimeric Mo species (respectively 22 and $145 \mu \mathrm{molg}^{-1}$ ).

\subsection{Interpretation of TOF values}

In ethylene ammoxidation, dimeric Mo over $\mathrm{Z} 26(\mathrm{MoCO})$ and $\mathrm{Z} 26\left(\mathrm{MoCl}_{3}\right)$ catalysts led to quasi-similar TOF values. However, in ethane ammoxidation, Eq. (2) was successfully catalyzed by monomeric Mo over Z26( $\left.\mathrm{MoCl}_{3}\right)$ catalyst (344 $\mu$ molg $^{-1}$ ), which explains the higher TOF value obtained at $500^{\circ} \mathrm{C}$ if compared with that of Z26(MoCO). The contribution of crystalline $\mathrm{MoO}_{3}$ in ethane ammoxidation over these two catalysts is not clear since their DRS spectra revealed a similar $\mathrm{E}_{\mathrm{g}}\left(\mathrm{MoO}_{3}\right)$ value $(2.96 \mathrm{eV})$. As for $\mathrm{BEA}(\mathrm{MoCO})$ and $\mathrm{BEA}\left(\mathrm{MoCl}_{5}\right)$, similar TOF values were obtained in ethylene ammoxidation. This behaviour is expected as these two solids loaded dimeric Mo at quasi-comparable concentrations. However, in ethane ammoxidation, we can notice (in Fig. 8A) the higher TOF values obtained with $\mathrm{BEA}\left(\mathrm{MoCl}_{5}\right)$ due to the contribution of monomeric Mo $\left(22 \mu \mathrm{molg}^{-1}\right)$ in the reaction illustrated in Eq. (2). Moreover, the contribution of crystalline $\mathrm{MoO}^{3}$ in Eq. (2) cannot be neglected over BEA(MoCO) due to the higher $\mathrm{C}_{2} \mathrm{H}_{4}$ activity obtained without the contribution of monomeric Mo $\left(\sim 4 \mu \mathrm{molg}^{-1}\right)$. Apparently, crystalline $\mathrm{MoO}_{3}$ exists in a highly dispersed state over BEA(MoCO) since no TPR features were observed in Fig. 5. However, over BEA $\left(\mathrm{MoCl}_{5}\right)$ catalyst, amorphous $\mathrm{MoO}_{3}$ catalyzed the secondary reaction in ethylene and ethane ammoxidation at $500^{\circ} \mathrm{C}$. Herein, we can attribute the peak at $510^{\circ} \mathrm{C}$ in the TPR profile of $\mathrm{BEA}\left(\mathrm{MoCl}_{5}\right)$ solid to amorphous $\mathrm{MoO}_{3}$.

Over $\mathrm{Z} 26\left(\mathrm{MoO}_{3}\right) 6 \% \mathrm{He}$ catalyst, the TOF values are insignificant between 425 and $450^{\circ} \mathrm{C}$ despite the presence of large crystallites of $\mathrm{MoO}_{3}$ which inhibit the diffusion of reactants toward active sites (i.e. $28 \mu \mathrm{molg}^{-1}$ of dimeric Mo). Nevertheless, at $500^{\circ} \mathrm{C}$, the highest TOF value was obtained. Apparently, increasing the temperature and the presence of oxygen as an ammoxidation reactant improved the dispersion state of crystalline $\mathrm{MoO}_{3}$ which catalyzes the reaction in Eq.(2) namely at $500^{\circ} \mathrm{C}$. This hypothesis has been confirmed by the XRD pattern of $\mathrm{Z} 26\left(\mathrm{MoO}_{3}\right) 6 \% \mathrm{O}_{2}$ in Fig. S10, which revealed the decrease in the intensity of $\mathrm{MoO}_{3}$ diffraction lines. On the other hand, the XPS analyses performed before and after catalytic tests indicate that $\mathrm{MoO}_{3}$ migrates from the internal cavities of $\mathrm{Z} 26\left(\mathrm{MoO}_{3}\right) 6 \% \mathrm{He}$ catalyst toward the surface. The inversed trend was observed over Z26(MoAcac) which exhibited very low TOF values.

The exchange of $\mathrm{MoO}_{2}\left(\mathrm{C}_{5} \mathrm{H}_{7} \mathrm{O}_{2}\right)_{2}$ into $\mathrm{ZSM}-5(\mathrm{Si} / \mathrm{Al}=26)$ favoured the agglomeration of amorphous $\mathrm{MoO}_{3}$ which diffuses inside the channels during test and inhibits the accessibility of reactants toward the $418 \mu \mathrm{molg}^{-1}$ of $\left[\mathrm{MoO}_{4}\right]^{2-}$ and the $\mu$ molg $^{-1}$ of $\left[\mathrm{Mo}_{2} \mathrm{O}_{7}\right]^{2-}$ active species ${ }^{[3,33]}$.

The exchange of $\mathrm{MoO}_{3}$ into $\mathrm{BEA}$ zeolite led to an active catalyst. In effect, $\mathrm{BEA}\left(\mathrm{MoO}_{3}\right)$ solid contains crystalline $\mathrm{MoO}_{3}$, monomeric Mo $\left(23 \mu \mathrm{molg}^{-1}\right)$ and $\left[\mathrm{Mo}_{2} \mathrm{O}_{7}\right]^{2-}\left(12 \mu \mathrm{molg}^{-1}\right)$ species. On the other hand, we noticed a linear increase in the TOF values between 425 and $500^{\circ} \mathrm{C}$, which points out that the dispersion state of crystalline $\mathrm{MoO}_{3}$ over $\mathrm{BEA}\left(\mathrm{MoO}_{3}\right)$ catalyst is kept intact during catalytic tests. Nevertheless, in the case of BEA(MoAcac), TOF values increase at high temperatures due to the improvement in the dispersion state of crystalline $\mathrm{MoO}_{3}$ (reducible under $\mathrm{H}_{2}$ at 590 and $660^{\circ} \mathrm{C}$ ). At low temperatures, TOF values are low since $\mathrm{BEA}(\mathrm{MoAcac})$ does not contains monomeric Mo, while $\mathrm{MoO}_{3}$ is present in the amorphous state (reducible under $\mathrm{H}_{2}$ at $510^{\circ} \mathrm{C}$ ).

The contribution of crystalline $\mathrm{MoO}_{3}$ in ethane oxidative dehydrogenation depended on its dispersion state. In this 
context, crystalline $\mathrm{MoO}_{3}$ over $\mathrm{BEA}\left(\mathrm{Mo}_{7} \mathrm{O}_{24}\right)$ solid (detected by XRD) was reduced under $\mathrm{H}_{2}$ at high temperatures $\left(730^{\circ} \mathrm{C}\right.$ vs. $700^{\circ} \mathrm{C}$ for $\mathrm{BEA}\left(\mathrm{MoO}_{3}\right)$ solid). Apparently, this oxide phase occupied the internal micropores due to the significant decrease in the SBET and the porosity of the support (see the table p. S13) and to the low concentrations of Mo at the surface. In ethane ammoxidation, $\mathrm{BEA}\left(\mathrm{Mo}_{7} \mathrm{O}_{24}\right)$ catalyst exhibited lower catalytic activity if compared with $\mathrm{BEA}\left(\mathrm{MoO}_{3}\right)$. This behaviour is due to the presence of crystalline $\mathrm{MoO}_{3}$ inside the micropores; such an oxide phase is inefficient in ammoxidation as also revealed over Z26(MoAcac) catalyst.

\subsection{Reference catalysts}

Starting from ZSM-5 $(\mathrm{Si} / \mathrm{Al}=26)$ and $\mathrm{MoO}_{3}$, very high Mo amount $(10 \mathrm{wt} . \%)$ improved the catalytic activity in ethylene ammoxidation at $500^{\circ} \mathrm{C}\left(26.50 \mu \mathrm{mols}^{-1} \mathrm{~g}^{-1}\right.$ over $\mathrm{Z} 26\left(\mathrm{MoO}_{3}\right) 10 \% \mathrm{He}$ vs. $8.90 \mu \mathrm{mols}^{-1} \mathrm{~g}^{-1}$ for $\left.\mathrm{Z} 26\left(\mathrm{MoO}_{3}\right) 6 \% \mathrm{He}\right)$. Apparently, the excess of Mo stabilizes higher amounts of mono- and dimeric active species (by analogy with $\left.\mathrm{Z} 26\left(\mathrm{MoO}_{3}\right) 6 \% \mathrm{He}\right)$ as well as crystalline $\mathrm{MoO}_{3}$. Nevertheless, the exchange of 6 wt. $\%$ of Mo over $\mathrm{ZSM}-5(\mathrm{Si} / \mathrm{Al}=140)$ led to low AN activity in $\mathrm{C}_{2} \mathrm{H}_{4}$ ammoxidation at $500^{\circ} \mathrm{C}\left(5.60 \mu \mathrm{mols}^{-1} \mathrm{~g}^{-1}\right.$ over $\mathrm{Z140}\left(\mathrm{MoO}_{3}\right) 6 \% \mathrm{He}$ vs. $8.90 \mu \mathrm{mols}^{-1} \mathrm{~g}^{-1}$ over $\left.\mathrm{Z} 26\left(\mathrm{MoO}_{3}\right) 6 \% \mathrm{He}\right)$. Due to the very high $\mathrm{Si} / \mathrm{Al}$ ratio (and very low $\left.\Delta_{\text {dehyd. }} \mathrm{H}\right), \mathrm{ZSM}-5$ zeolite $(\mathrm{Si} / \mathrm{Al}=140$ ) seems hydrophobic and, therefore, the transformation of $\mathrm{MoO}_{3}$ into $\mathrm{MoO}_{2}(\mathrm{OH})_{2}$ (Eq. 11) and then into active species (via Eqs. 12 and 13) does not take place. In effect, the textural properties of $\mathrm{Z} 140\left(\mathrm{MoO}_{3}\right) 6 \% \mathrm{He}$ and $\mathrm{Z} 140\left(\mathrm{MoO}_{3}\right) 6 \% \mathrm{O}_{2}$ (page S13) are quite-similar, evidencing that $\mathrm{MoO}_{3}$ does not diffuse inside the channels in the absence of $\mathrm{H}_{2} \mathrm{O}$.

The humid impregnation of a hydrophobic zeolite $(\mathrm{ZSM}-5, \mathrm{Si} / \mathrm{Al}=40)$ with $\mathrm{MoO}_{3}$ at 2 and $4 \mathrm{wt}$ \% of $\mathrm{Mo}\left(\mathrm{Z} 40\left(\mathrm{MoO}_{3}\right)\right.$ Imp2\% and $\mathrm{Z} 40\left(\mathrm{MoO}_{3}\right) \operatorname{Imp} 4 \%$, respectively) led to 15.50 and $18 \mu \mathrm{mols}^{-1} \mathrm{~g}^{-1}$ of $\mathrm{AN}$ activity. These catalytic activities exceed those obtained with the highly hydrophobic ZSM-5 $(\mathrm{Si} / \mathrm{Al}=140)$ despite the use of low Mo wt. \%. This behaviour is due to the fact that $\mathrm{ZSM}-5(\mathrm{Si} / \mathrm{Al}=40)$ retained $\mathrm{H}_{2} \mathrm{O}$ molecules during the impregnation which favours the formation of $\mathrm{MoO}_{2}(\mathrm{OH})_{2}$ (Eq. 11) and the stabilization of active species (Eqs. 12 and 13). The impregnation of 4 wt. \% of Mo into a hydrophilic zeolite $(\mathrm{ZSM}-5, \mathrm{Si} / \mathrm{Al}=15)$, i.e. $\mathrm{Z} 15\left(\mathrm{MoO}_{3}\right) \mathrm{Imp} 4 \%$ solid, led to the highest activity $\left(29.70 \mu \mathrm{mols}^{-1} \mathrm{~g}^{-1}\right.$ of AN activity at $500^{\circ} \mathrm{C}$ vs. $17.80 \mu \mathrm{mols}^{-1} \mathrm{~g}^{-1}$ over $\left.\mathrm{Z} 40\left(\mathrm{MoO}_{3}\right) \mathrm{Imp} 4 \%\right)$. In particular, 4 wt. \% of Mo exchanged with hydrophobic or hydrophilic zeolite led to very high AN selectivity at low temperatures. Apparently, in a water-rich atmosphere, 2 wt. \% of Mo are inefficient to produce enough active species from $\mathrm{MoO}_{3}$ since the textural properties of $\mathrm{Z} 15\left(\mathrm{MoO}_{3}\right) \operatorname{Imp} 2 \%$ and ZSM-5 zeolite $(\mathrm{Si} / \mathrm{Al}=15)$ are similar (page S13), i.e. there is no residual $\mathrm{MoO}_{3}$ able to clog the zeolite channels.

\section{Conclusion}

We studied the light hydrocarbons conversion into acetonitrile over Mo exchanged zeolites. In ethylene ammoxidation, the most active catalysts are those prepared by the humid impregnation of $\mathrm{MoO}_{3}(4 \mathrm{wt}$. \%) into MFI zeolite, having low dehydration enthalpy $\Delta_{\text {dehyd. }} \mathrm{H}\left(11.70 \mathrm{kJmol}{ }^{-1}, \mathrm{Si} / \mathrm{Al}\right.$ ratio $\left.=15\right)$. Nevertheless, increasing Si/Al ratio from 15 to 40 or decreasing the metal amount from 4 to $2 \mathrm{wt}$. \% decreased the selectivity toward the desired product. On the other hand, the exchange of high amount of $\mathrm{MoO}_{3}(10 \mathrm{wt} . \%)$ by solid-state ion exchange method is suitable but the use of hydrophobic zeolites (very high Si/Al ratios, i.e. 140) should be avoided. In effect, water molecules are required to transform $\mathrm{MoO}_{3}$ into the exchangeable $\mathrm{MoO}_{2}(\mathrm{OH})_{2}$ species. Starting from $\mathrm{NH}_{4}{ }^{+} \mathrm{BEA}\left(\mathrm{Si} / \mathrm{Al}=12.21, \Delta_{\text {dehyd. }} \mathrm{H}=13.94 \mathrm{kJmol}^{-1}\right)$ and $\mathrm{NH}_{4}{ }^{+}-$ ZSM-5 zeolite ( $\left.\mathrm{Si} / \mathrm{Al}=26, \Delta_{\text {dehyd }} \mathrm{H}=7.60 \mathrm{k} J \mathrm{~mol}-1\right)$ and using $\mathrm{MoO}_{3}$ precursor, the corresponding catalysts are very active at high temperatures $\left(500^{\circ} \mathrm{C}\right)$ due to the stabilization of crystalline $\mathrm{MoO}_{3}$. In ethane and ethylene ammoxidation, $\left[\mathrm{MoO}_{4}\right]^{2-}$, $\left[\mathrm{Mo}_{2} \mathrm{O}_{7}\right]^{2-}$ and crystalline $\mathrm{MoO}_{3}$ are the active species. However, due to their particular structures and higher dehydration enthalpy values, FER, OFF and MOR zeolites do not allow the stabilization of these species. Furthermore, $\mathrm{MoOCl}_{4}$, $\mathrm{Mo}(\mathrm{CO})_{6}, \mathrm{MoCl}_{3}$ should be avoided as they stabilize inefficient $\left[\mathrm{Mo}_{7} \mathrm{O}_{24}\right]^{6-}$ species and amorphous $\mathrm{MoO}_{3}$. By choosing the adequate precursors $\left(\mathrm{MoCl}_{5}, \mathrm{MoO}_{2}\left(\mathrm{C}_{5} \mathrm{H}_{7} \mathrm{O}_{2}\right)_{2}\right.$ and $\left.\mathrm{MoO}_{3}\right)$ the dehydration state of the zeolite (i.e. $\Delta_{\text {dehyd. }} \mathrm{H}$ and $\mathrm{Si} / \mathrm{Al}$ values) would be taken in consideration.

\section{Acknowledgement}

Emna Mannei and Faouzi Ayari:

We would like to thank Pr. Zouhaier Ksibi for giving us the opportunity to perform scientific research in the Material chemistry and catalysis laboratory.

This article contains supplementary information online at: http://ojs.wiserpub.com/index.php/FCE/article/view/117/115 


\section{References}

[1] Neal L, Haribal V, McCaig J et al. Modular-scale ethane to liquids via chemical looping oxidative dehydrogenation: Redox catalyst performance and process analysis. J Adv Manuf Process. 2019; 1: 1-8.

[2] Gue E. Midstream MLPs: The best way to ride the U.S. petrochemical wave. Seeking Alpha. Available from: https:// seekingalpha.com/article/4042473-midstream-mlps-best-way-ride-u-s-petrochemical-wave. [Accessed 27th, June 2017].

[3] Mannei E, Ayari F, Petitto C et al. Light hydrocarbons ammoxidation into acetonitrile over Mo-ZSM-5 catalysts: Effect of molybdenum precursor. Microporous Mesoporous Mater. 2017; 241: 246-257.

[4] Mannei E, Ayari F, Asedegbega-Nieto E et al. Physicochemical and catalytic properties of over- and low-exchanged Mo-ZSM-5 ammoxidation catalysts. Chem Papers. 2019; 73: 619-633.

[5] Mannei E, Ayari F, Asedegbega-Nieto E et al. Catalytic behaviour of molybdenum-based zeolitic materials prepared by organic-medium impregnation and sublimation methods. J. Iran. Chem. Soc. 2019. Available from: https://doi. org/10.1007/s13738-019-01837-6.

[6] Li Y, Armor JN. Ammoxidation of ethane to acetonitrile over metal-zeolite catalysts. J Catal. 1998; 173: $511-518$.

[7] Jeong Y-S, An SH and Shin C-H. Selective synthesis of acetonitrile by reaction of ethanol with ammonia over Ni/ A12O3 catalyst. Korean J Chem Eng. 2019; 36: 1051-1056.

[8] Boschloo G, Hagfeldt A. Characteristics of the iodide/triiodide redox mediator in dye-sensitized solar cells. Acc Chem Res. 2009; 42: 1819-1826.

[9] Partington JR, Cowley EG. Dipole moment of acetonitrile. Nature. 1935; 135: 474.

[10] The Phamraceutical Journal, Acetonitrile shortage. Available from: https://www.pharmaceutical-journal.com/newsand-analysis/acetonitrile-shortage/10047706.article?firstPass=false. [Accessed 29th, January 2009]

[11] Essid S, Ayari F, Bulánek R et al. Over- and low-exchanged Co/BEA catalysts: General characterization and catalytic behaviour in ethane ammoxidation. Catal Today. 2018; 304: 103-111.

[12] Essid S, Ayari F, Bulánek R et al. Improvement of the conventional preparation methods in Co/BEA zeolites: Characterization and ethane ammoxidation. Solid State Sci. 2019; 93: 13-23.

[13] Mitchell PCH. Molybdenum in enzymatic and heterogeneous catalysis. J Inorg Biochem. 1986; 28: 107-123.

[14] Ferdjaoui NH, El Berrichi FZ and Ayari F. Kaolin-issued zeolite A as efficient adsorbent for Bezanyl Yellow and Nylomine Green anionic dyes. Microporous Mesoporous Mater. 2017; 243: 91-101.

[15] Breck DW, Grose RW. A Correlation of the calculated intracrystalline void volumes and limiting adsorption volumes in zeolites. In: Molecular Sieves. Advances in Chemistry. ACS Washington DC; 1973. p. 319-329.

[16] Kosinov N, Coumans FJAG, Uslamin E et al. Selective coke combustion by oxygen pulsing during Mo/ZSM-5catalyzed methane dehydroaromatization. Angew Chem. 2016; 128: 15310-15314.

[17] Arnoldy P, de Jonge JCM and Moulijn JA. Temperature-programmed reduction of $\mathrm{MoO}_{3}$ and $\mathrm{MoO}_{2}$. J Phys Chem. 1985; 89: 4517-4526.

[18] Ayari F, Mannei E, Asedegbega-Nieto E et al. More insight on the isothermal spreading of solid $\mathrm{MoO}_{3}$ into ZSM-5 zeolite. React Kin, Mech Catal. 2018; 124: 419-436.

[19] Mannei E, Ayari F, Mhamdi M et al. Ammoxidation of $\mathrm{C}_{2}$ hydrocarbons over Mo-zeolite catalysts prepared by solidstate ion exchange: Nature of molybdenum species. Microporous Mesoporous Mater. 2016; 219: 77-86.

[20] Vieillard P, Mathieu R. A predictive model for the enthalpies of hydration of zeolites. Amer Miner. 2009; 94: $565-577$.

[21] Djajanti SD, Howe RF. MOCVD in zeolites using Mo(CO) ${ }_{6}$ and W(CO) ${ }_{6}$ as precursors. Stud Surf Sci Catal. 1995; 97 : 197-204.

[22] Mon Y, Win Kyi L. Performance comparison of Gauss elimination and Gauss-Jordan elimination. Int J Comput Commun Eng Res. 2014; 2: 67-71.

[23] Bhaskar T, Reddy KR, Kumar CP et al. Characterization and reactivity of molybdenum oxide catalysts supported on zirconia. Appl Catal A: Gen. 2001; 211: 189-201.

[24] Ayari F, Mannei E, Asedegbega-Nieto E et al. Elucidation of the solid-state ion exchange mechanism of $\mathrm{MoCl}_{5}$ into ZSM-5 zeolite. Thermochim Acta. 2017; 655: 269-277.

[25] Mirodatos C, Abou-Kais A, Vedrine JC et al. Characterization of the hydroxyls in offretite zeolite. J Chem Soc, Faraday Trans. 1978; 74: 1786-1795.

[26] Zhang R, Liu N, Lei Z et al. Selective transformation of various nitrogen-containing exhaust gases toward N2 over zeolite catalysts. Chem Rev. 2016; 116: 3658-3721.

[27] $\mathrm{Hu} \mathrm{H}$, Ke M, Zhang K et al. Designing ferrierite-based catalysts with improved properties for skeletal isomerization of n-butene to isobutene. RSC Adv. 2017; 7: 31535-31543.

[28] Kerr IS. Structure of ferrierite. Nature. 1966; 210: 294-295.

[29] Verbiest J,Vansant EE. Dehydration, deammoniation and thermal stability of ferrierite. Bull Soc Chim Belq. 1986; 95 : 
$75-81$.

[30] Miwa M, Suzuki K, Katada N et al. Ammonia IRMS-TPD study on the distribution of acid sites in mordenite. J Phys Chem B. 2005; 109: 18749-18757.

[31] Hadded N, Bordes-Richard E, Hilaire L et al. MoOx-based catalysts for the oxidative dehydrogenation (ODH) of ethane to ethylene: Influence of vanadium and phosphorus on physicochemical and catalytic properties. Catal Today. 2007; 126: 256-263.

[32] Batalha N, Soualah A, Pinard L et al. Impact of the BEA zeolite morphology on isobutane adsorption followed by reversed-flow inverse gas chromatography. J Chromatogr A. 2012; 1260: 206-214.

[33] Ayari F, Mannei E, Asedegbega-Nieto E et al. Solid-state ion exchange of molybdenum (VI) acetylacetonate into ZSM-5 zeolite. Thermochim Acta. 2017; 652: 150-159. 